$12-15-2013$

\title{
Late Glacial and Holocene Record of Climatic Change in the Southern Rocky Mountains from Sediments in San Luis Lake, Colorado, USA
}

\author{
Fasong Yuan \\ Cleveland State University, f.yuan06@csuohio.edu \\ Max R. Koran \\ Cleveland State University \\ Awlthethisaddezadditional works at: https://engagedscholarship.csuohio.edu/scibges_facpub \\ at Sand Punes National Park \\ Part of the Biology Commons \\ How does access to this work benefit you? Let us know! \\ Publisher's Statement \\ NOTICE: this is the author's version of a work that was accepted for publication in \\ Palaeogeography, Palaeoclimatology, Palaeoecology. Changes resulting from the publishing \\ process, such as peer review, editing, corrections, structural formatting, and other quality control \\ mechanisms may not be reflected in this document. Changes may have been made to this work \\ since it was submitted for publication. A definitive version was subsequently published in \\ Palaeogeography, Palaeoclimatology, Palaeoecology, 392, December 15, 2013 10.1016/ \\ j.palaeo.2013.09.016
}

\section{Recommended Citation}

Yuan F, Koran MR, Valdez A. 2013. Late glacial and Holocene record of climatic change in the southern Rocky Mountains from sediments in San Luis Lake, Colorado, USA. Palaeogeogr, Palaeoclimatol, Palaeoecol. 392:146-60.

This Article is brought to you for free and open access by the Biological, Geological, and Environmental Sciences Department at EngagedScholarship@CSU. It has been accepted for inclusion in Biological, Geological, and Environmental Faculty Publications by an authorized administrator of EngagedScholarship@CSU. For more information, please contact library.es@csuohio.edu. 


\title{
Late Glacial and Holocene record of climatic change in the southern Rocky Mountains from sediments in San Luis Lake, Colorado, USA
}

\author{
Fasong Yuan ${ }^{\mathrm{a}, *}$, Max R. Koran ${ }^{\mathrm{a}}$, Andrew Valdez ${ }^{\mathrm{b}}$ \\ a Department of Biological, Geological, and Environmental Sciences, Cleveland State University, Cleveland, OH 44115, USA \\ b Great Sand Dunes National Park, Mosca, CO 81146, USA
}

\section{Introduction}

The southern Rocky Mountains are the headwaters for several large rivers (e.g., the Colorado River and the Rio Grande) and represent a critical water resource for many fast growing communities in the arid American Southwest (Costigan et al., 2000), a region where recent warming is among the most rapid in the United States (Karl et al., 2009). The 20022004 drought is a reminder that the future changes in climate may exacerbate the ecological vulnerability of this already dry region (Quiring and Goodrich, 2008). Numerical climate models have already predicted that the ongoing warming will enhance the existing pattern of effective moisture $(P-E)$ and cause modern subtropical drylands to become even more arid (Held and Soden, 2006). Nevertheless, constraining the climate models with geologic records is an essential step toward improving our ability to understand climate change and plan for the future.

Over the last decades, efforts to search for the past changes in climate have recovered a number of paleoclimate records across the

\footnotetext{
* Corresponding author. Tel.: +1 216687 3508; fax: +1 2166876972 .

E-mail addresses: f.yuan06@csuohio.edu (F. Yuan), m.r.koran@csuohio.edu (M.R. Koran), andrew.valdez@nps.gov (A. Valdez).
}

southwestern United States which documented periods of wet anomalies, extreme droughts, warmer and/or cooler temperatures, based on plant macrofossils and pollen in packrat middens (e.g., Van Devender, 1977; Thompson and Anderson, 2000; Betancourt et al., 2001), aquatic fossils in lakes (Shafer, 1989; Anderson, 1993; Jimenez-Moreno et al. 2008), speleothems in caves (Polyak and Asmerom, 2005; Asmerom et al., 2007; Wagner et al., 2010), and floral distributions at high plains (Fall, 1997; Vierling, 1998; Toney and Anderson, 2006). Many of these records spanning the Late Glacial and Holocene are broadly consistent in indicating an orbital-scale transition from a cooler and wetter Late Glacial to a warmer and drier Holocene. But much uncertainty regarding the timing and nature of millennial-scale climatic changes remains. There is a long-standing debate about the relative aridity of the midHolocene in this region (Spaulding, 1991; Barron et al., 2012). Some studies suggested that the mid-Holocene was a time of drier conditions relative to those of today (Menking and Anderson, 2003; Toney and Anderson, 2006; Shuman et al., 2009), while others indicated that wetter conditions prevailed at least parts of this time period (Krider, 1998; Anderson et al., 2008; Briles et al., 2012).

Sediments from closed-basin lakes represent a key archive of climatic and environmental changes because they are highly sensitive to changes 
in hydroclimate and widely distributed on land (Street and Grove, 1979). Oxygen isotope record of Owens Lake documents the existence of millennial-scale hydrologic oscillations during the last glacial termination (Benson et al., 1997). Holocene records from Walker and Pyramid Lakes indicate decadal to centennial-scale hydroclimatic variability in the Sierra Nevada (Benson et al., 2002; Yuan et al., 2004). Stable isotope records from alpine lakes over the Colorado Rocky Mountains suggest that the climate shifted from a greater summer precipitation in the early Holocene to a winter-dominated precipitation regime in the midHolocene (Friedman et al., 1988; Anderson, 2011; Anderson, 2012). These studies provide us important isotopic data on the past changes in climate over the American Southwest. However, lake-based $\delta^{18} \mathrm{O}$ records spanning the entire Late Glacial and Holocene transition (LGHT) are scarce in this region.

Here we describe our efforts to reconstruct climatic and environmental changes in the southern Rocky Mountains during the Late Glacial and Holocene. We chose San Luis Lake mainly because it sits at the southern edge of the annual latitudinal range of the Pacific winter storm tracks and on the northern limit of the North American monsoon (NAM) rainfall regime (Metcalfe et al., 1997; Barron et al., 2012; Ellis and Barton, 2012). Changes in either winter or summer precipitation regime may alter the lake's hydrology, isotope geochemistry and depositional environment. Past work on this basin has showed that deposits from certain locations may be appropriate for paleoclimate reconstructions (Shafer, 1989; Rogers et al., 1992; De Lanois, 1993). We collected sediment cores from San Luis Lake and carried out a series of physical and chemical analyses, including magnetic susceptibility, grain size, total inorganic carbon (TIC), $\mathrm{Mg} / \mathrm{Ca}, \delta^{18} \mathrm{O}$, and $\delta^{13} \mathrm{C}$, to indicate climatic and environmental changes over the last $16.5 \mathrm{ka}$. Results from radiometric dating analyses (C-14, Pb-210, Cs-137 and Ra-226) are obtained for age control. Our sediment record from San Luis Lake documented a detailed history of climatic and environmental changes in the southern Rocky Mountains since the last glacial maximum. We compared our record from San Luis Lake with existing paleoclimate data from Colorado and elsewhere in the American Southwest and distant regions to gain novel insights into the changes in hydroclimate over the southern Rocky Mountains during the Late Glacial and Holocene.

\section{Study area}

San Luis Lake $\left(37.675^{\circ} \mathrm{N}, 105.723^{\circ} \mathrm{W}\right)$ is located in a large intermountain basin between the San Juan Mountains and the Sangre de Cristo Mountains in southern Colorado (Fig. 1). Geologically, this basin is a structural depression that formed during the Cenozoic stretching of the Rio Grande rift (Cordell, 1978; Brister and Gries, 1994), with a drainage area of about $8300 \mathrm{~km}^{2}$ and an average altitude of $2350 \mathrm{~m}$ (Emery, 1979). The flat floor of the basin is now occupied by a complex array of eolian, fluvial, and alluvial deposits, underlain by a suite of sediment formations with ages from Eocene to Pleistocene which overlies on the Precambrian basement (Brister and Gries, 1994). The basin had remained hydrologically closed, disintegrated with ancestral Rio Grande, and sustained a large freshwater lake called Lake Alamosa (Siebenthal, 1910) for about three million years before it drained back to the Rio Grande approximately 440 ka (Rogers et al., 1992; Machette et al., 2007). San Luis Lake is a small closed-basin lake today, with a surface area of $\sim 3.6 \mathrm{~km}^{2}$, which lies in a topographically low area near the eastern margin of the basin (Fig. 1b). Saguache and San Luis creeks are two major streams in the basin but become ephemeral before reaching San Luis Lake. As many wetlands investigated previously (Wurster et al., 2003), San Luis Lake is hydrologically affected by the water table of the basin (Mayo et al., 2007).

The climate of the region is characterized as arid, with an average annual temperature of $5.5^{\circ} \mathrm{C}$ (Emery, 1979). There is an inverse relationship in precipitation seasonality between the basin floor and the surrounding mountains (Doesken and McKee, 1989). The mountain precipitation $(70 \mathrm{~cm} / \mathrm{yr})$ is largely from winter storms originating in the
North Pacific Ocean whereas the basin floor precipitation $(18 \mathrm{~cm} / \mathrm{yr})$ is dominated by summer rainfall from the NAM (Mitchell, 1976; Doesken and McKee, 1989). As a result, a bimodal precipitation distribution is present in this basin (Shafer, 1989). Winter precipitation over the region is known to be associated with the El Niño Southern Oscillation (ENSO). The amount of winter precipitation usually increases during El Niño events and decreases during La Niña events (Redmond and Koch, 1991; Cayan, 1996). In contrast, the amount of monsoonal rainfall is affected by the ENSO in opposing circumstances to that of winter precipitation (Higgins et al., 1998; Weiss et al., 2009). El Niño favors a weaker and more southward-displaced monsoon ridge (Castro et al., 2001) and tends to reduce the number of monsoonal storms (Webb and Betancourt, 1992).

\section{Methods}

\subsection{Core acquisition, magnetic susceptibility, and grain-size distribution}

Two sediment cores were recovered in January 2010, with a landbased vibracorer and a gasoline powered generator (Thompson et al., 1991). One was taken from the southwestern side (SL-A/B) of San Luis Lake at a water depth of $\sim 1 \mathrm{~m}$ and the other from a dry wetland site (BL-01) in Blanca Wetland Area (Fig. 1b, c). Core SL-A/B had a total length of $261 \mathrm{~cm}$ and core BL-01 was $222 \mathrm{~cm}$ in length. The two cores were measured on magnetic susceptibility at $1-\mathrm{cm}$ intervals with a Bartington MS2C unit, then split lengthwise, described and imaged. One half of the core was slab sampled at every $1-\mathrm{cm}$ interval for sedimentologic, geochemical and isotopic analyses and the other half was sampled for radiometric dating analysis. Sediment samples were wet sieved with deionized water and divided into two portions using a 230 mesh $(63 \mu \mathrm{m})$ sieve. The coarse portion was air dried, further sieved with a set of two sieves ( $250 \mu \mathrm{m}$ and $2 \mathrm{~mm}$ ), and weighted with an Ohaus CS200 compact digital scale. The fine portion was collected, oven dried overnight at $60{ }^{\circ} \mathrm{C}$, weighted, and then homogenized with a mortar and pestle (Yuan et al., 2006b). Sediment powder was soaked in $2.5 \% \mathrm{NaClO}$ for $6-8 \mathrm{~h}$ to remove organic matter, vacuum filtered with a Whatman glass microfiber filter $(1.6 \mu \mathrm{m})$, rinsed with deionized water at least five times, and oven dried at $60{ }^{\circ} \mathrm{C}$ with a petri dish prior to isotopic analyses (Yuan et al., 2006b).

The percentages of four different grain-size fractions $(\phi>2 \mathrm{~mm}$, $2 \mathrm{~mm}>\phi>250 \mu \mathrm{m}, 250 \mu \mathrm{m}>\phi>63 \mu \mathrm{m}, \phi<63 \mu \mathrm{m})$ were estimated by weight. Grain-size distribution for each sediment sample was evaluated with the weight percentages. A 3-point log-linear interpolation was used to estimate the effective grain size $\left(d_{10}\right)$, the mean grain size $\left(d_{50}\right)$, and the grain size that is $60 \%$ finer by weight $\left(d_{60}\right)$. The uniformity coefficient of a sediment sample, as an indicator of sediment sorting, was calculated by the ratio of $d_{60}$ to $d_{10}$ (Fetter, 2000).

\subsection{Elemental and isotopic analysis}

The molar ratio of $\mathrm{Mg} / \mathrm{Ca}$ was determined on acid extracts of sediment samples with $10 \% \mathrm{HNO}_{3}$, using an inductively coupled plasma optical emission spectrometer and the \%TIC content was determined through coulometric analysis of $\mathrm{CO}_{2}$ produced after acidifying sediment samples with $2 \mathrm{~N} \mathrm{HClO}_{4}$ (Engleman et al., 1985), using a UIC CM5014 coulometer at Case Western Reserve University. Oxygen and carbon isotopic analyses were performed simultaneously on a Micromass Optima gas source mass spectrometer with a MultiPrep automated sample preparation device at University of Albany, New York. The isotopic results, calibrated against NBS-19, are reported in the delta $(\delta)$ notation as per mil (\%) relative to the Vienna Pee Dee Belemnite (PDB) standard. The overall precision for internal and external standards was $\pm 0.1 \%$ for $\delta^{18} \mathrm{O}$ and $\delta^{13} \mathrm{C}$. 
(a)

(b)
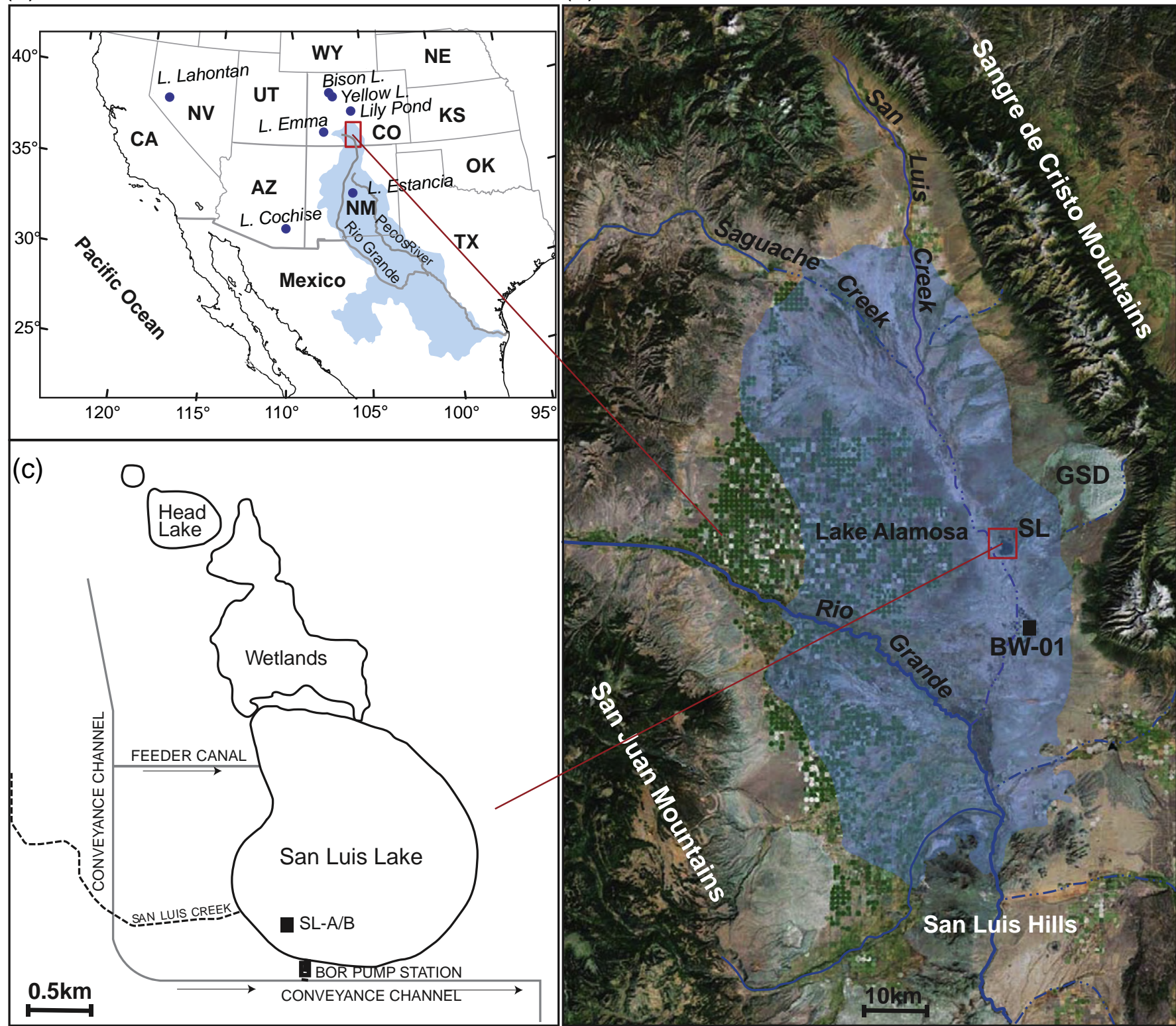

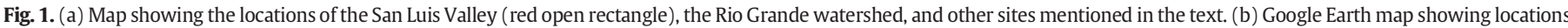

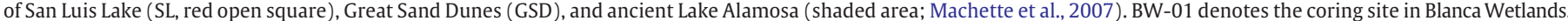
(c) Enlarged line map showing locations of San Luis Lake and Head Lake. SL-A/B denotes the coring site in the lake.

\subsection{Radiometric analysis}

Thirty eight samples from the topmost section of core BL-01 were measured on Pb-210, Cs-137, and Ra-226 at Flett Research Laboratory in Canada. There is a distinct peak at a depth of $15 \mathrm{~cm}$ in the Cs-137 activity profile (Fig. 2), corresponding to the 1963 maximum in Cs137 atmospheric fallout (Ritchie et al., 1973). Pb-210 activity in this core has an essentially vertical profile in the interval of $0-15 \mathrm{~cm}$ and then generally decreases as a function of depth (Fig. 3). The Ra-226 activities measured in four depths indicate that the background $\mathrm{Pb}-210$ activity level has been achieved at the bottom of the core, and that background levels of Pb-210 vary with depth in this core. The unsupported $\mathrm{Pb}-210$ activity values were deduced and the constant rate of supply (CRS) model was used to derive ages for sediments in the topmost $15 \mathrm{~cm}$ section (Appleby and Oldfield, 1978). A second-order polynomial fit was used to extrapolate the calendar age of the sediments at a depth of $49 \mathrm{~cm}$ (Fig. 4), at which sediments were also radiocarbon dated (Table 1).

Seven radiocarbon ages from core BL-01 and two from core SL-A/B were determined on the total organic carbon (TOC) fraction of the bulk sediments by the Accelerator Mass Spectrometry Laboratory at the University of Arizona (Table 1). Past work on this basin suggested that radiocarbon ages of lake sediments were subject to reservoir corrections due to the inputs of radiocarbon-free dissolved inorganic carbon from weathering of carbonate-bearing formations (Shafer, 1989). The reservoir effect may be estimated by the radiocarbon age of surface sediments, assuming that the carbon dynamics remained more or less constant in the past. Based on the difference between the radiocarbon age (1280 yr BP) and the extrapolated calendar age (280 yr BP) of the sediments from core BL-01 at a depth of $49 \mathrm{~cm}$ (Table 1 and Fig. 4), 
Cs-137 (DPM/g)

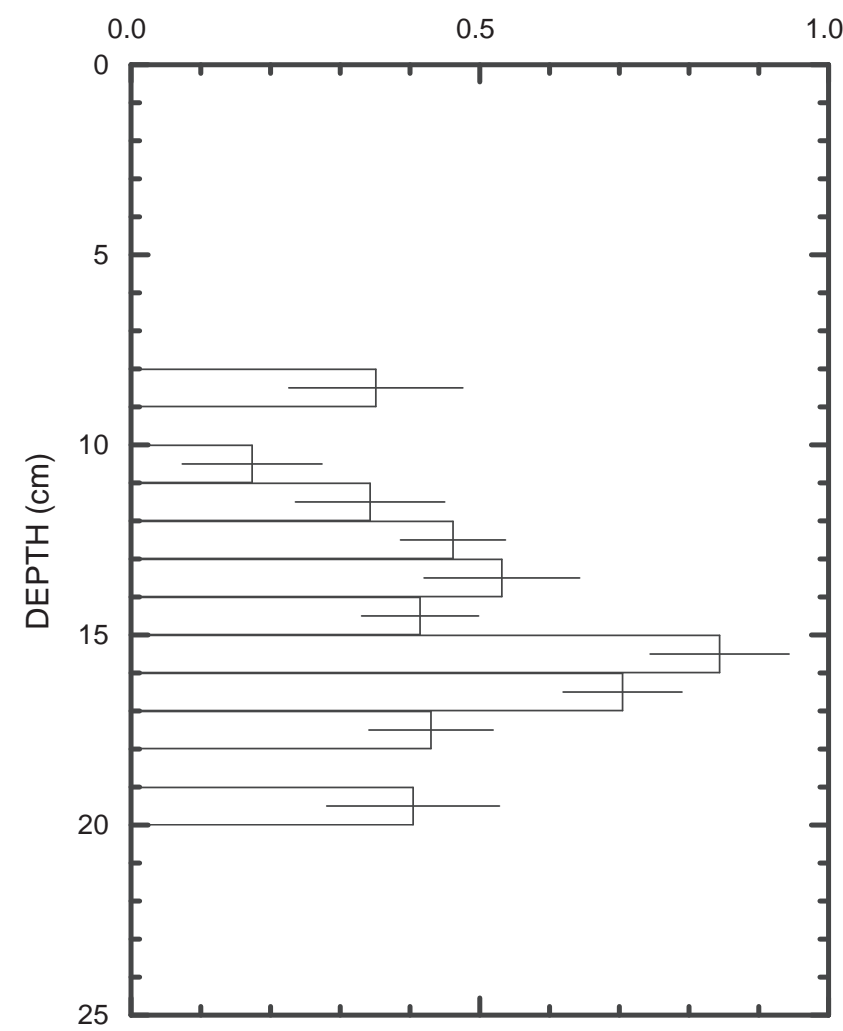

Fig. 2. Sediment profile of Cs-137 activity from core BL-01. Note the peak in ${ }^{137} \mathrm{Cs}$ at a depth of $15 \mathrm{~cm}$, corresponding to the 1963 maximum in ${ }^{137} \mathrm{Cs}$ atmospheric fallout (Ritchie et al., 1973).

we deduced that the reservoir effect was about 1000 yr for core BL-01, comparable with the reservoir effect of San Luis Lake, as previously reported (Shafer, 1989).
CALENDAR AGE (yrs bp)

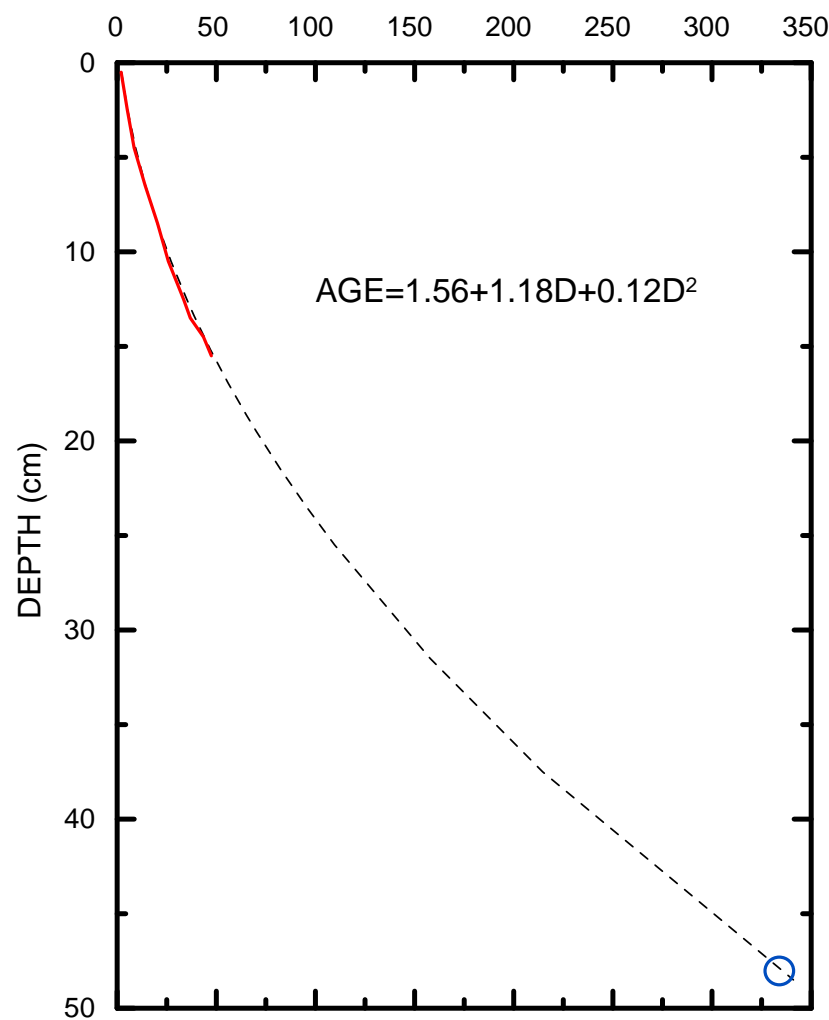

Fig. 4. Calendar ages deduced from measurements of $\mathrm{Pb}-210$, Cs-137 and Ra-226 for the topmost section $(37 \mathrm{~cm}$ ) of core BL-01 (red line). Age model was derived from a second-order polynomial fit of the topmost $15 \mathrm{~cm}$ sediments with the deduced ages (dash line). Note that the extrapolated calendar age of sediments at a depth of $49 \mathrm{~cm}$ is $\sim 340 \mathrm{yr}$ bp (before 2010), equivalent to $280 \mathrm{yr}$ BP (before 1950).

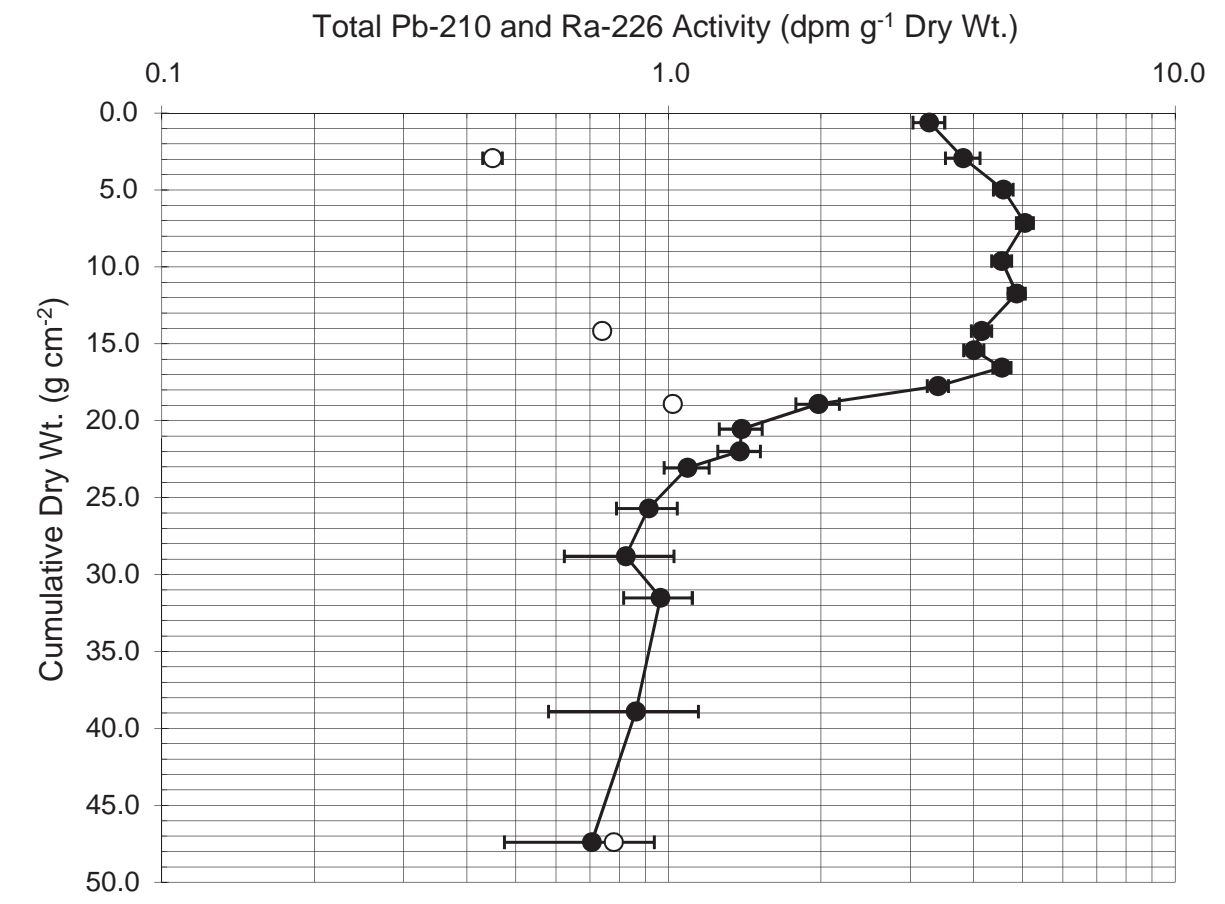

Fig. 3. Plot of total Pb-210 (filled circles) and Ra-226 (open circles) activity against cumulative dry weight for the topmost section of core BL-01. 
Table 1

Radiocarbon dates from San Luis Lake.

\begin{tabular}{|c|c|c|c|c|c|c|}
\hline \multirow[t]{2}{*}{ Core \# } & \multirow[t]{2}{*}{ AA lab \# } & \multirow[t]{2}{*}{$\begin{array}{l}\text { Depth } \\
(\mathrm{cm})\end{array}$} & \multirow{2}{*}{$\begin{array}{l}\text { Radiocarbon } \\
\frac{\text { age }^{\mathrm{a}}}{\left({ }^{14} \mathrm{C} \text { yr BP }\right)}\end{array}$} & \multirow{2}{*}{$\begin{array}{l}1-\sigma \\
\frac{\text { Error }}{( \pm \mathrm{yr})}\end{array}$} & \multirow{2}{*}{$\begin{array}{l}\text { Calibrated } \\
\frac{\text { age }^{\text {b }}}{\text { (cal yr BP) }}\end{array}$} & \multirow{2}{*}{$\begin{array}{l}2-\sigma \\
\text { Error } \\
( \pm \mathrm{yr})\end{array}$} \\
\hline & & & & & & \\
\hline \multicolumn{7}{|l|}{ BL-01 } \\
\hline & AA90470 & 49 & 1280 & 140 & 286 & 231 \\
\hline & AA90471 & 79 & 3310 & 240 & 2321 & 553 \\
\hline & AA90472 & 136 & 9060 & 430 & 8979 & 960 \\
\hline & AA90473 & 150 & 2060 & 120 & $(961)^{c}$ & 224 \\
\hline & AA90474 & 172 & 9630 & 860 & 9936 & 2146 \\
\hline & AA90475 & 190 & 17,800 & 3100 & 20,222 & 7637 \\
\hline & AA90476 & 221 & 19,100 & 2600 & 21,648 & 6392 \\
\hline \multicolumn{7}{|l|}{ SL-A/B } \\
\hline & AA90478 & 100 & 13,800 & 1700 & $(14,477)$ & 4264 \\
\hline & AA90479 & 257 & 15,400 & 2100 & 16,322 & 5231 \\
\hline
\end{tabular}

${ }^{a}$ Total organic carbon fraction of the sediments was used for the radiocarbon dating analyses.

b Calendar ages were calculated through the computer program CALIB Rev 6.0.1 (Stuiver and Reimer, 1993) and reservoir corrections estimated were $1500 \mathrm{yr}$ for SL-A/B (Shafer, 1989) and $1000 \mathrm{yr}$ for BL-01.

c Ages in parentheses were excluded for age model development.

\subsection{Core correlation and age control}

On the basis of downcore variations in magnetic susceptibility, the two cores were stratigraphically correlated, particularly the upper sections of the cores (Fig. 5). Owing to a lack of organic carbon for reliable radiocarbon dating, we depended largely on the peak to peak correlations between the two cores to deduce the radiocarbon ages of the topmost four major peaks for core SL-A/B. The radiocarbon ages were converted into calendar ages with the CALIB radiocarbon calibration program (Stuiver and Reimer, 1993). Together with the basal date from core $\mathrm{SL}-\mathrm{A} / \mathrm{B}$, five ages were gathered and used to develop our age model using a second-order polynomial fit (Fig. 6).

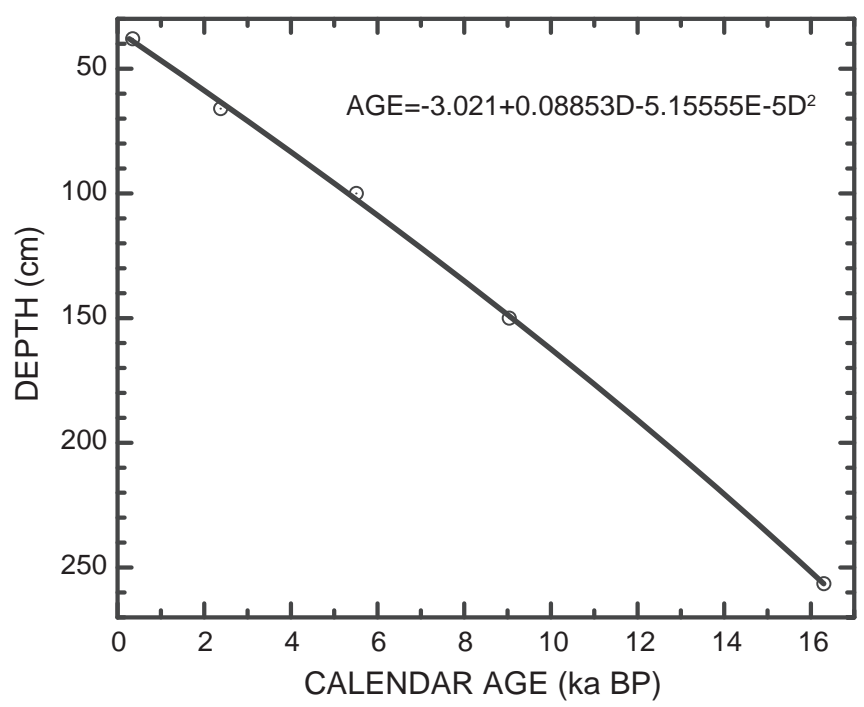

Fig. 6. Age model for core SL-A/B.

\section{Results}

\subsection{Lithostratigraphy, grain size and magnetic susceptibility}

Sediments from core SL-A/B are composed of unconsolidated erosive sands, silts and clayey minerals. Visual inspection of the split core surface indicates the presence of some laminations and considerable variations in sediment grainsize distribution throughout the core (Fig. 7a). Two sediment layers near depths of $75 \mathrm{~cm}$ and $110 \mathrm{~cm}$ contain some coarser particles with the grain size over $2 \mathrm{~mm}$, while the bottom $60-\mathrm{cm}$ section lack such coarser particles (Fig. 7f). The sediments are constituted largely of the medium $(0.25-2.0 \mathrm{~mm})$ and, to less extent, the fine (63-250 $\mu \mathrm{m})$ grain fractions. There is a complementary relationship between the medium and fine grain fractions (Fig. 7c, d).

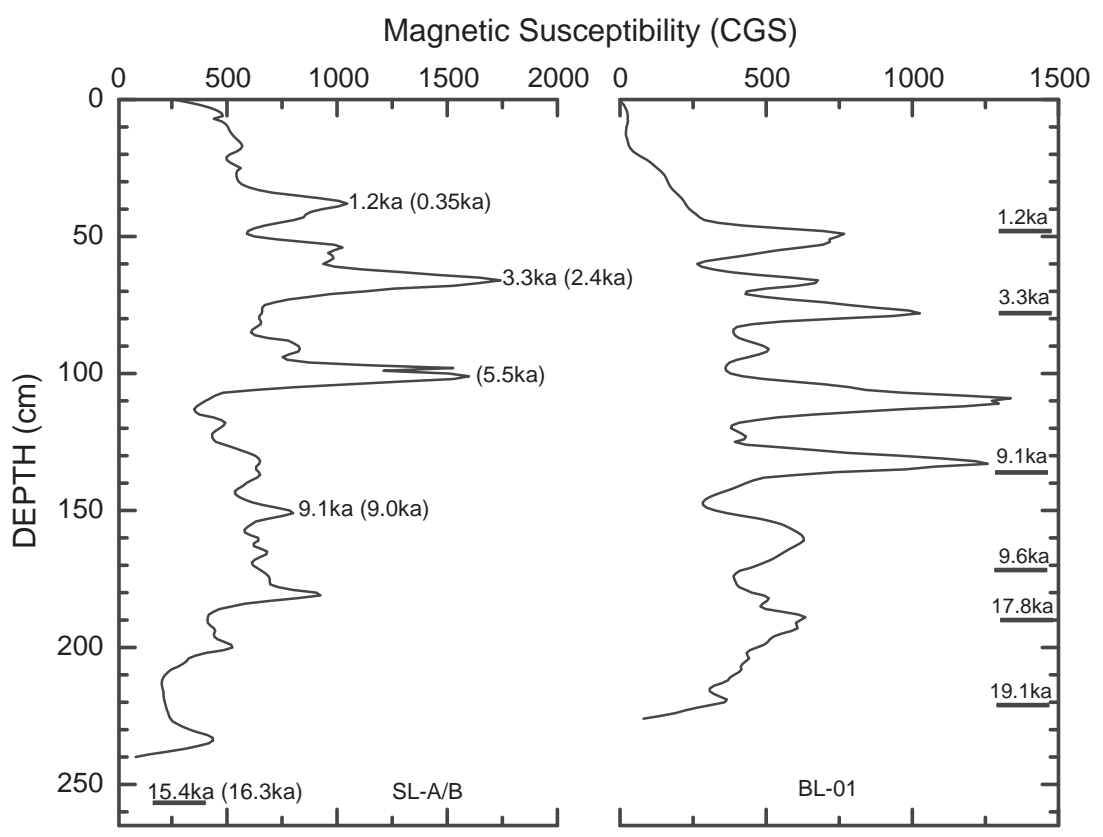

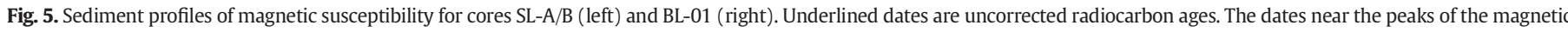

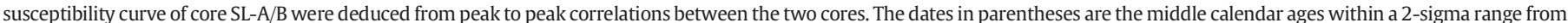

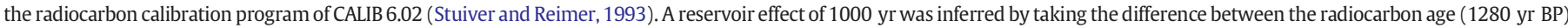

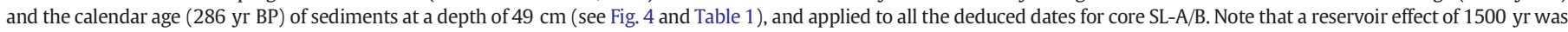
used for the radiocarbon dates of SL-A/B (Shafer, 1989). 


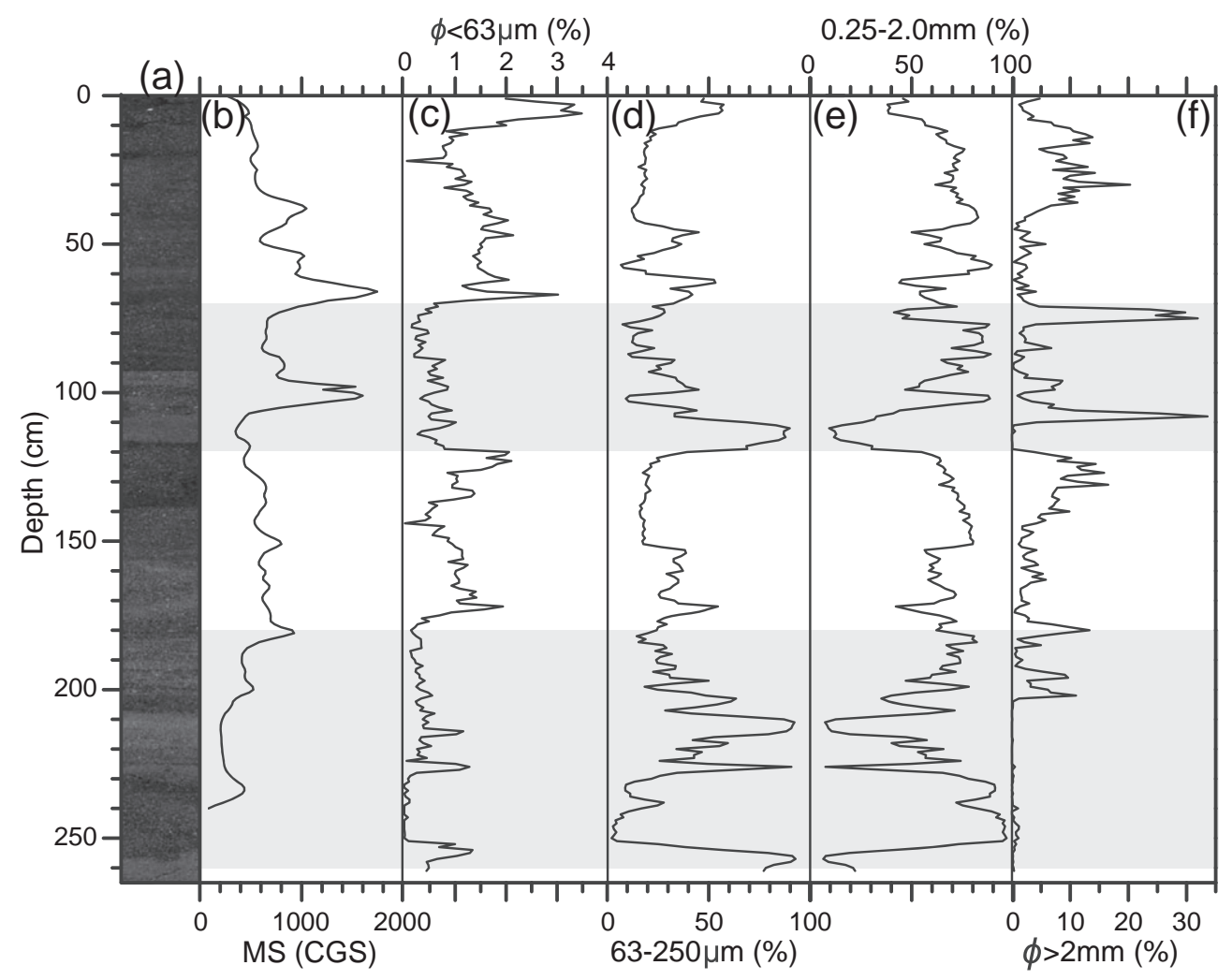

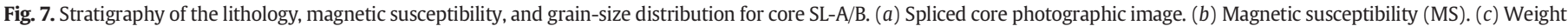

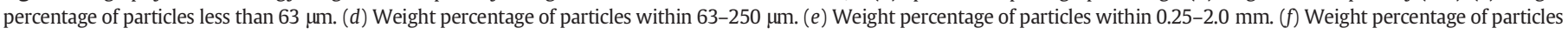
over $2.0 \mathrm{~mm}$.

The fine grain fraction dominates in four intervals centered at depths of $261 \mathrm{~cm}, 225 \mathrm{~cm}, 210 \mathrm{~cm}$, and $118 \mathrm{~cm}$. The very fine $(<63 \mu \mathrm{m})$ grain fraction usually accounts for less than $3.5 \%$ by weight and changes considerably (trace to over 3\%) throughout the core. Sediments from the middle and bottom sections as highlighted in Fig. 7e have lower percentage values of the very fine fraction than those from other sections.

The magnetic susceptibility record of core SL-A/B displays large amplitude of variability (Fig. 7b). Values of magnetic susceptibility are

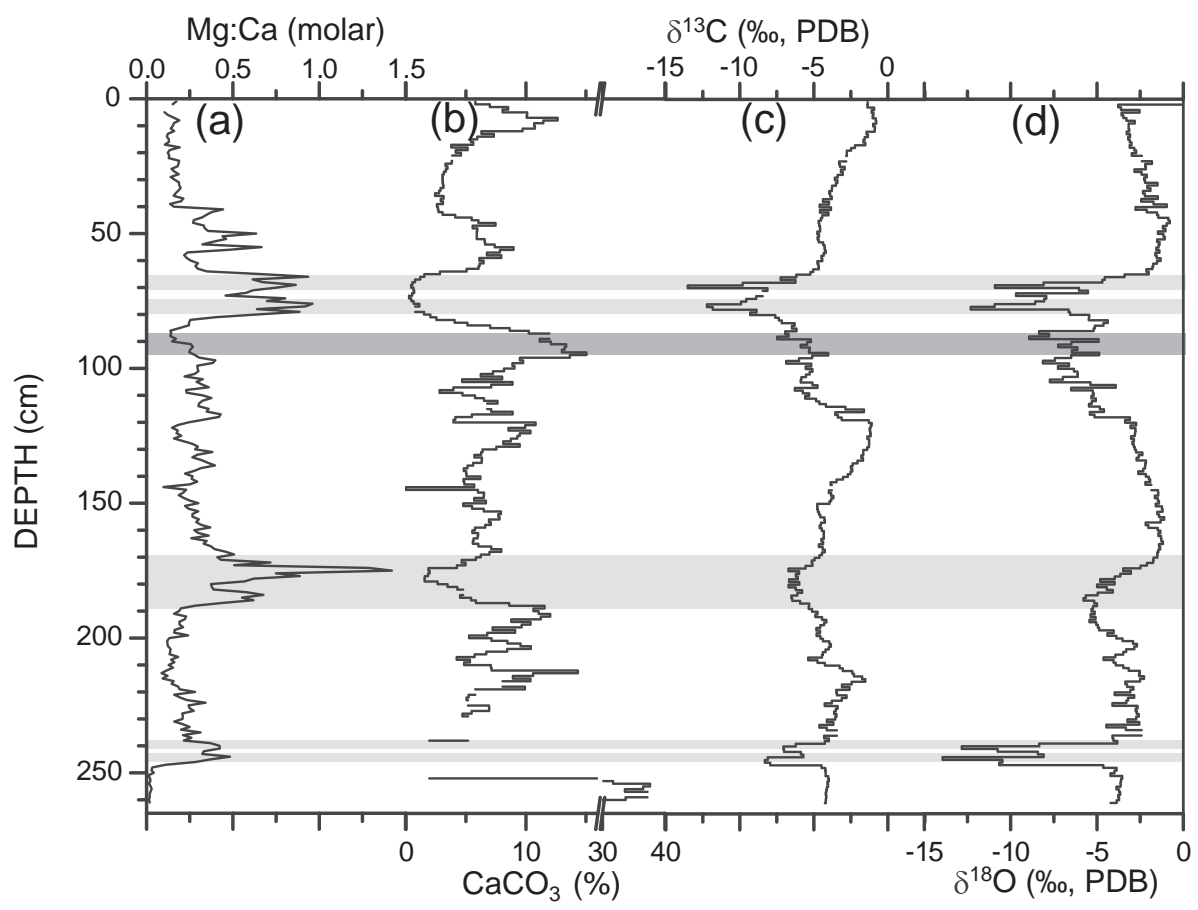

Fig. 8. Downcore variations in $\mathrm{Mg} / \mathrm{Ca}(a), \% \mathrm{CaCO}_{3}(b), \delta^{13} \mathrm{C}(c)$, and $\delta^{18} \mathrm{O}(d)$ of sediments in San Luis Lake. 
relatively low in the bottom section, reach a maximum at a depth of $180 \mathrm{~cm}$, and then decrease gradually until a depth of $110 \mathrm{~cm}$. There are two prominent peaks at depths of $100 \mathrm{~cm}$ and $65 \mathrm{~cm}$, followed by an interval with progressive decreases in magnetic susceptibility. There are some degrees of similarity between the magnetic susceptibility and the medium fraction records, particularly in the upper section of the core (Fig. 7b, c). Magnetic susceptibility data from the bottom 21-cm section are missing due to some technical difficulty while measuring.

\section{2. $\mathrm{Mg} / \mathrm{Ca}$ and TIC}

The $\mathrm{Mg} / \mathrm{Ca}$ molar ratio varies substantially throughout the core (Fig. 8a). Sediments from the basal section $(261-250 \mathrm{~cm})$ of the core have low $\mathrm{Mg} / \mathrm{Ca}$ ratios, with an average of 0.02 . The ratio increases abruptly to a maximum of 0.5 at a depth of $245 \mathrm{~cm}$, decreases gradually before reaching a minimum at a depth of $215 \mathrm{~cm}$, and then increases progressively until it achieves a maximum at a depth of $175 \mathrm{~cm}$. The $\mathrm{Mg} / \mathrm{Ca}$ ratio oscillates moderately in a depth interval between 165 and $100 \mathrm{~cm}$ before achieving a maximum at a depth of $80 \mathrm{~cm}$, and then decreases stepwise in the upper section of the core.

The TIC as measured by $\% \mathrm{CaCO}_{3}$ of the fine grain fraction of sediments fluctuates greatly throughout the core (Fig. 8b). The TIC values are exceptionally large $(\sim 34 \%)$ in the basal section $(261-252 \mathrm{~cm})$ and oscillate considerably in the interval of $229-80 \mathrm{~cm}$, with an average of $7 \%$ and a standard deviation of $2.8 \%$. There are two depth intervals from 190 to $180 \mathrm{~cm}$ and from 95 to $80 \mathrm{~cm}$, with large (over 10\%) decreases in TIC. Although not strongly correlated, some peak-to-trough correspondences are evident between the $\mathrm{Mg} / \mathrm{Ca}$ and TIC records (Fig. 8a, b). A gap of TIC data from $251-230 \mathrm{~cm}$ is due to a lack of sufficient fine grain sediments.

\section{3. $\delta^{13} \mathrm{C}$ and $\delta^{18} \mathrm{O}$}

$\delta^{13} \mathrm{C}$ and $\delta^{18} \mathrm{O}$ as determined on the TIC fraction of the fine sediment material from San Luis Lake are characterized by relatively large variability, with $\delta^{13} \mathrm{C}$ ranging from -13 to $2.8 \%$ and $\delta^{18} \mathrm{O}$ from -14 to $0.7 \%$ ( Fig. 8 c, d). $\delta^{13} \mathrm{C}$ values remain relatively constant in the bottom section of the core (depth $>250 \mathrm{~cm}$ ), decrease abruptly to $-8 \%$ at a depth of $250 \mathrm{~cm}$, and then increase stepwise to $-1 \%$ at a depth of $215 \mathrm{~cm}$. $\delta^{13} \mathrm{C}$ decreases stepwise from 215 to $175 \mathrm{~cm}$ and increases progressively from 175 to $120 \mathrm{~cm}$. Depth interval from 120 to $65 \mathrm{~cm}$ is featured with increased isotopic variability, in which $\delta^{13} \mathrm{C}$ decreases progressively and peaks at 78 and $69 \mathrm{~cm} . \delta^{13} \mathrm{C}$ values increase gradually in the topmost $65 \mathrm{~cm}$ section.

The $\delta^{13} \mathrm{C}$ and $\delta^{18} \mathrm{O}$ records exhibit a great deal of similarity, particularly in intervals with pronounced isotopic variations. But there are some depth intervals with opposing trends. For instance, $\delta^{18} \mathrm{O}$ increases gradually while $\delta^{13} \mathrm{C}$ decreases in the two depth intervals from 170 to $120 \mathrm{~cm}$ and from 65 to $2 \mathrm{~cm}$. As highlighted in Fig. 8, minima in $\delta^{13} \mathrm{C}$ and $\delta^{18} \mathrm{O}$ tend to coincide with periods of low TIC and high $\mathrm{Mg} / \mathrm{Ca}$ ratio and vice versa.

\section{Data interpretation and discussion}

\subsection{Hydroclimate variability from elemental and isotopic data}

The stratigraphic variations in $\delta^{18} \mathrm{O}$ and $\delta^{13} \mathrm{C}$ of lacustrine carbonates can be caused by variations in temperature and the isotopic compositions of lake water (i.e., $\delta^{18} \mathrm{O}$ of $\mathrm{H}_{2} \mathrm{O}$ and $\delta^{13} \mathrm{C}$ of $\mathrm{HCO}_{3}^{-}$). Changes in water temperature affect isotopic fractionation between the evaporating water vapor and lake water and between the carbonate precipitate and lake water. Every $1{ }^{\circ} \mathrm{C}$ increase in water temperature may cause a $0.1 \%$ increase in $\delta^{18} \mathrm{O}$ of the water vapor (Benson and Paillet, 2002), a $0.2 \%$ decrease in $\delta^{18} \mathrm{O}$ of the lake carbonate (O'Neil et al., 1969), and a $0.035 \%$ o decrease in $\delta^{13} \mathrm{C}$ of the lake carbonate (Romanek et al., 1992). Compared to the large (14\%) range of isotopic variations observed in
San Luis Lake (Fig. 9a), the effect of temperature may be rather limited. Thus, we take the stratigraphic changes in $\delta^{18} \mathrm{O}$ and $\delta^{13} \mathrm{C}$ as representing the temporal variations in $\delta^{18} \mathrm{O}$ and $\delta^{13} \mathrm{C}$ of lake water, as shown by previous studies from other lakes in the western United States (Li et al., 1997; Yuan et al., 2006a; Anderson, 2011).

$\delta^{18} \mathrm{O}$ of lake water is determined largely by $\delta^{18} \mathrm{O}$ of precipitation and basin hydrology. In lakes that oscillate between closed and open hydrological states, $\delta^{18} \mathrm{O}$ of lake water fluctuates greatly with changing residence time of water in the basin (Benson et al., 1997). When a lake overflows, the residence time is relatively short and $\delta^{18} \mathrm{O}$ of lake water is usually more negative and variable. Under the extreme case when the residence time approaches zero, $\delta^{18} \mathrm{O}$ of lake water resembles that of stream inflows into the lake. In contrast, when a lake remains hydrologically closed, the residence time is relatively long and $\delta^{18} \mathrm{O}$ of lake water is usually more positive due to preferential enrichment of 0-18 during evaporation. For lakes with a fluctuating water balance, $\delta^{18} \mathrm{O}$ of lake water increases as the lake contracts and vice versa. Under certain circumstances (e.g., hydrologic steady-state conditions), lake water may be highly 0-18 enriched in relative to precipitation and changes in $\delta^{18} \mathrm{O}$ of lake water is largely induced by variations in $\delta^{18} \mathrm{O}$ of precipitation due to variable precipitation regimes over the drainage basin (Gat, 1995; Benson et al., 1997; Li et al., 2008).

$\delta^{13} \mathrm{C}$ of lake water (mainly bicarbonate) is controlled by three major components, namely $\delta^{13} \mathrm{C}$ of stream inflows, $\mathrm{CO}_{2}$ exchange with atmosphere, and primary productivity within the lake (Leng and Marshall, 2004). First, $\delta^{13} \mathrm{C}$ of stream inflows is largely determined by $\delta^{13} \mathrm{C}$ of $\mathrm{CO}_{2}$ from root respiration and microbial oxidation of organic matter in soils and the subsequent equilibrium fractionation between $\mathrm{CO}_{2}$ and bicarbonate anion (Ode et al., 1980; Benson et al., 1996). $\delta^{13} \mathrm{C}^{2} \mathrm{CO}_{2}$ derived from C4 organic matter ranges from -32 to $-20 \%$, while $\delta^{13} \mathrm{C}$ of $\mathrm{CO}_{2}$ from $\mathrm{C} 3$ plants (arid grasses) ranges from -17 to $-9 \%$. Bicarbonate anion, the dominant dissolved inorganic species under weakly alkaline conditions, has $\delta^{13} \mathrm{C}$ values approximately $10 \%$ higher than $\mathrm{CO}_{2}$ (Romanek et al., 1992). Thus, if all the $\mathrm{CO}_{2}$ in the soil zone is derived from C4 plants, $\delta^{13} \mathrm{C}$ of bicarbonate anion is estimated to range from -22 to $-10 \%$. Based on isotopic measurements of stream, spring, and shallow ground waters (Mayo et al., 2007), $\delta^{13} \mathrm{C}$ of inflows into San Luis Lake is $-11.5 \pm 3.5 \%$, falling in the high end of the range estimated. Second, $\delta^{13} \mathrm{C}$ of atmospheric $\mathrm{CO}_{2}$ is about $-7 \%$ o (Keeling, $1961)$ and the bicarbonate in equilibrium with the atmospheric-derived $\mathrm{CO}_{2}$ has a $\delta^{13} \mathrm{C}$ value between +1 and $+3 \%$ o (Benson et al., 1996; Leng and Marshall, 2004). Owing to its slowness in achieving gas-exchange equilibrium, a higher value of $\delta^{13} \mathrm{C}$ is indicative of a longer residence time of lake water and a higher degree of equilibrium of the bicarbonate anion with the atmospheric $\mathrm{CO}_{2}$ (Benson et al., 1996; Leng and Marshall, 2004). Lastly, changes in the net primary productivity affect the $\delta^{13} \mathrm{C}$ of lake water due to a preferential uptake of lighter isotopic species (i.e., ${ }^{12} \mathrm{C}$ ) by aquatic plant communities (Stuiver, 1975).

The TIC as measured on lake sediments can be a useful indicator of abrupt changes in lake levels because it is related to the lake's hydrological conditions. The TIC value is determined by the balance between the in-lake production of carbonates and siliciclastic dilution of detrital inputs from fluvial and eolian processes, provided that detrital carbonate inputs are minimal (Benson et al., 1997). A lake's primary production is limited by the amount of dissolved calcium input which is a linear function of stream discharge. In contrast, the amount of detrital input is an exponential function discharge (Benson et al., 2002). As a result, the \%TIC tends to decrease as stream discharge increases. But there are some degrees of uncertainty in this interpretation as the TIC may be affected by other factors such as changes in lake levels, groundwater tables, soil moisture conditions, or wind regimes.

$\mathrm{The} \mathrm{Mg} / \mathrm{Ca}$ ratio of lacustrine carbonates has been used as a proxy of salinity for many lake-based reconstructions (e.g., Chivas et al., 1986; Holmes, 1996). Ionic data from 27 lakes in western Nebraska showed an intriguing relationship between $\mathrm{Mg} / \mathrm{Ca}$ and salinity. Although positively correlated over a broad range of ionic concentrations, the two 


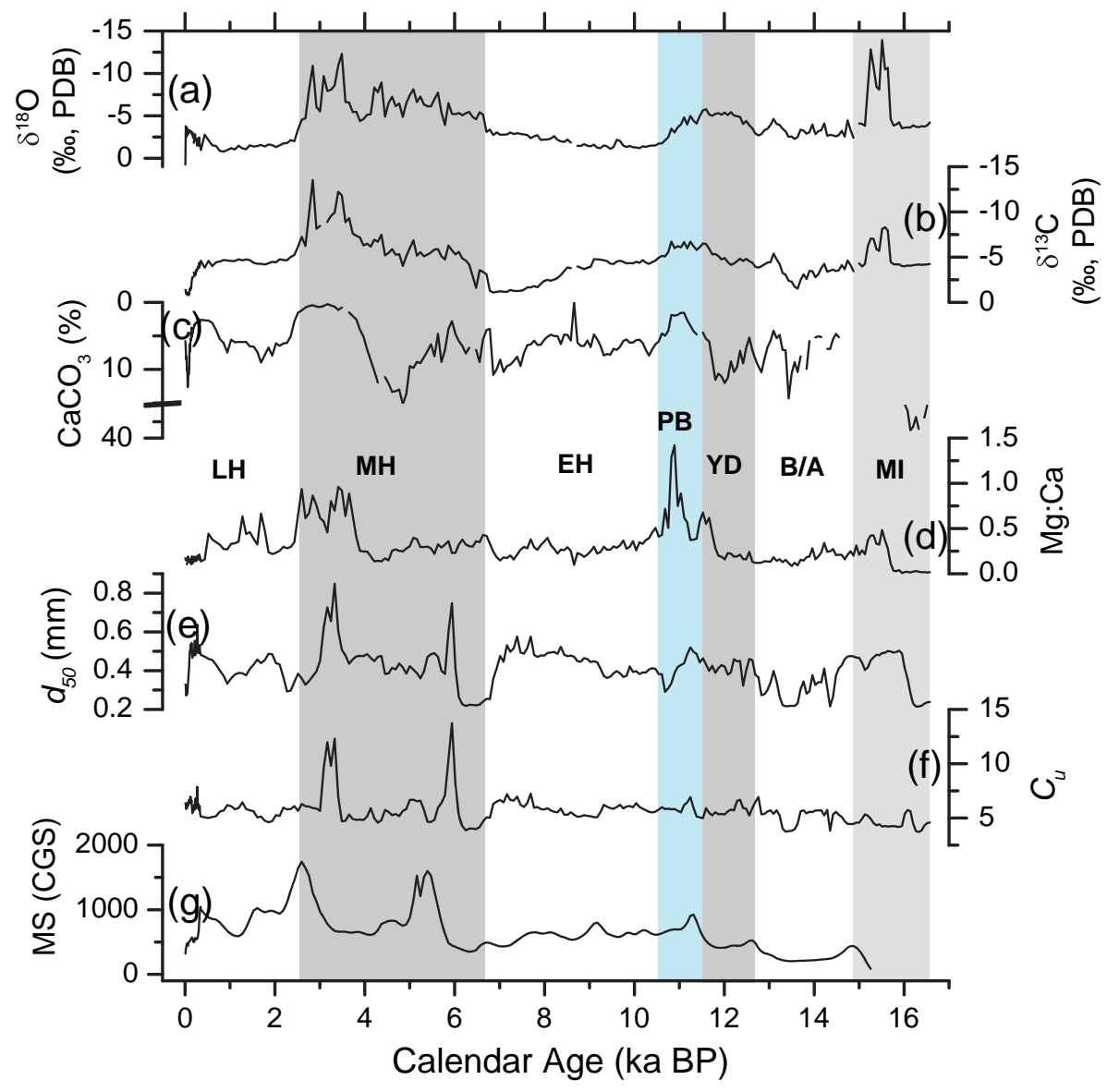

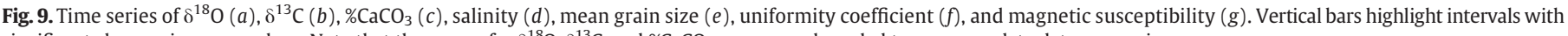
significant changes in proxy values. Note that the y-axes for $\delta^{18} \mathrm{O}, \delta^{13} \mathrm{C}$, and $\% \mathrm{CaCO}_{3}$ are reversely scaled to accommodate data comparisons.

indices are negatively correlated for some lakes with low salinity values (Gosselin, 1997). A recent study from Jones Lake in western Montana further attested to the existence of a negative correlation between $\mathrm{Mg} / \mathrm{Ca}$ and salinity, which was attributed to some common characteristics of groundwater throughflow lakes, such as high alkalinity, low $\mathrm{Mg} / \mathrm{Ca}$, and low salinity (Shapley et al., 2010). San Luis Lake has some similar hydrologic and geochemical characteristics, e.g., groundwater-fed, low salinity, and low $\mathrm{Mg} / \mathrm{Ca}$ today. Further, we found evidence that San Luis Lake overflowed occasionally in the past (see discussion below). Thus, we take an increase in $\mathrm{Mg} / \mathrm{Ca}$ ratio as representing a decrease in salinity and a corresponding increase in water balance and vice versa.

Our sediment record from San Luis Lake exhibits some degrees of similarity among four indices of $\delta^{18} \mathrm{O}, \delta^{13} \mathrm{C}$, TIC, and $\mathrm{Mg} / \mathrm{Ca}$ (Fig. 9a, b, c, d). In particular, there is a statistically significant correlation between $\delta^{18} \mathrm{O}$ and $\delta^{13} \mathrm{C}\left(r^{2}=0.41, n=257\right)$ though the correlation changes from time to time (Fig. 10). On the basis of the long-term trends and changes in these proxy values, the San Luis Valley was relatively dry during the Big Dry (16.5-15.7 ka) (Broecker et al., 2009), the BøllingAllerød (B/A: 14.9-12.7 ka), the early Holocene (EH: 10.5-6.7 ka), and the late Holocene ( $\mathrm{LH}: 2.5-0 \mathrm{ka}$ ), and relatively wet during the Big Wet (15.7-14.9 ka), and the Younger Dryas (YD: 12.7-11.6 ka), the Pre-Boreal (PB: 11.6-10.5 ka), and the mid-Holocene (MH: 6.7-2.5 ka). During these dry periods, San Luis Lake was featured with relatively high values of $\delta^{18} \mathrm{O}, \delta^{13} \mathrm{C}$, and TIC, and low ratios of $\mathrm{Mg} / \mathrm{Ca}$. We inferred that San Luis Lake remained hydrologically closed, received little detrital input from stream inflows, and were enriched with heavy isotope species such as $\mathrm{C}-13$ and $\mathrm{O}-18$. These periods are characterized by low isotopic variations and weak and even negative correlations of $\delta^{18} \mathrm{O}$ and $\delta^{13} \mathrm{C}$ (Fig. 10). We postulated that San Luis Lake might have achieved hydrologic steady-state conditions. If so, changes in $\delta^{18} \mathrm{O}$ of the lake were largely caused by changes in $\delta^{18} \mathrm{O}$ of precipitation while changes in $\delta^{13} \mathrm{C}$ were induced by varying degrees of equilibrium of gas exchange between atmospheric $\mathrm{CO}_{2}$ and lake water (Leng and Marshall, 2004). During the $\mathrm{EH}$, for instance, $\delta^{18} \mathrm{O}$ of the lake decreased steadily due to a greater

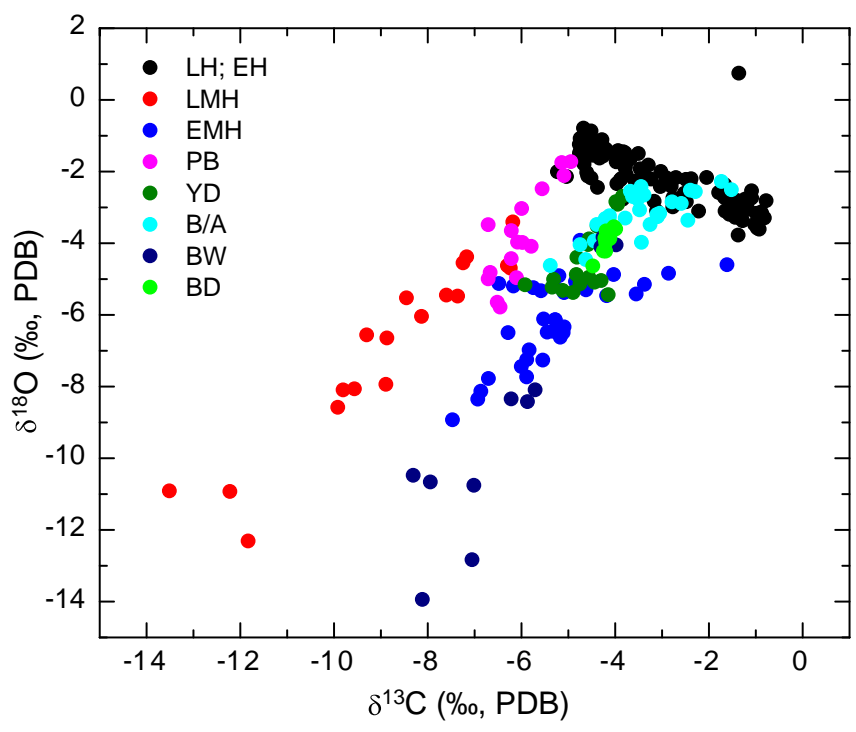

Fig. 10. Correlation between $\delta^{13} \mathrm{C}$ and $\delta^{18} \mathrm{O}$ in time intervals of the Big Dry (BG), the Big Wet (BW), the Bølling-Allerød (B/A), the Younger Dryas (YD), the Pre-Boreal (PB), the early Holocene $(E H)$, the early mid-Holocene $(E M H)$, the late mid-Holocene (LMH), and the late Holocene ( $\mathrm{LH})$. 
summer moisture regime shifting toward winter-dominated precipitation, while $\delta^{13} \mathrm{C}$ increased progressively with increasing $\mathrm{CO}_{2}$ gas exchange over the time. This may explain why $\delta^{18} \mathrm{O}$ and $\delta^{13} \mathrm{C}$ were negatively correlated in this time interval.

On the other hand, San Luis Lake was more fluctuating in wet times. First, the dominant moisture source changed considerably over the time. Most of the wet events were attributed to an increase in winter precipitation from the Pacific storm tracks. But the PB wet episode was characterized by an increase in summer precipitation from the $\mathrm{NAM}$, as inferred from an increasing trend of $\delta^{18} \mathrm{O}$, a minimum in TIC and a maximum in $\mathrm{Mg} / \mathrm{Ca}$ (Fig. 9). An increase in $\delta^{18} \mathrm{O}$ may be induced by either an increasing dominance of summer moisture regime from enhanced monsoonal circulations or a decreasing water balance of the lake. The minimum in TIC and maximum in $\mathrm{Mg} / \mathrm{Ca}$ suggest a high lake level in the lake. This interpretation is supported by archeological and paleobotanical evidence of a higher water table in this basin between 10.9 and 10.5 ka (Jodry and Stanford, 1996). Second, San Luis Lake may have overflowed occasionally during the Big Wet and $\mathrm{MH}$. Supporting evidence of this assertion includes extremely low values of $\delta^{18} \mathrm{O}, \delta^{13} \mathrm{C}$, and TIC, increased variability in $\delta^{18} \mathrm{O}$ and $\delta^{13} \mathrm{C}$, and high ratios of $\mathrm{Mg} / \mathrm{Ca}$. The minimal values of $\delta^{18} \mathrm{O}$ and $\delta^{13} \mathrm{C}$ in our record are close to those observed on modern streams and subsurface waters in this basin $\left(\delta^{18} \mathrm{O}=-14 \%\right.$ ond $\delta^{13} \mathrm{C}=-11 \%$, Mayo et al., 2007), suggesting a significant reduction in the residence time of water in the lake. The reduced residence time from increased water supply and subsequently lake overflowing resulted in a reduction in carbonate production and an increase in $\mathrm{Mg} / \mathrm{Ca}$ ratio. The increased isotopic variability further attests to lake oscillations between open and closed hydrological states. Third, the YD wet event is featured by a $3 \%$ decrease in $\delta^{18} \mathrm{O}$ and a $2 \%$ decrease in $\delta{ }^{13} \mathrm{C}$, suggesting a decrease in the residence time of water in the lake.

The correlation of $\delta^{18} \mathrm{O}$ and $\delta^{13} \mathrm{C}$ was used to indicate the degree of hydrological closure of a lake (Talbot, 1990; Li and Ku, 1997; Leng and Marshall, 2004). As pointed out by Benson et al. (1996), the concept may be applicable to some lakes but exceptions to this rule exist. Our results from San Luis Lake show that the degree of $\delta^{18} \mathrm{O}$ and $\delta^{13} \mathrm{C}$ covariance changed considerably from dry to wet hydrological conditions (Fig. 10). Generally, $\delta^{18} \mathrm{O}$ and $\delta^{13} \mathrm{C}$ covaried well when the lake was more fluctuating. The isotopic covariance was previously ascribed to hydroclimate-driven changes in lake organic productivity (Talbot, 1990; Drummond et al., 1995). Owing to the large range of isotopic variability observed, we attribute the isotopic covariance to variations in the residence time of water in the lake. A reduction in the residence time from an increase in overflow/inflow ratio would cause $\delta^{18} \mathrm{O}$ and $\delta^{13} \mathrm{C}$ of the lake to be more negative and vice versa.

\subsection{Environmental change from physical property data}

Grain size of lake sediments is a function of precipitation, runoff, lake level, and other factors (e.g., Benson et al., 1991; Conroy et al., 2008). Coarse material may be transported to the core site when a lake is shallow or saline. Sediment-trapping studies showed that suspended coarse material was transported in several kilometers in plumes of freshwater over the surface saline water in Pyramid Lake, Nevada (Anderson, 2001). Alternatively, fine to medium-grained material can be carried into a lake by strong winds (Bui et al., 1989). Because of its proximity to the Great Sand Dunes, San Luis Lake may have received some of the sediment material by eolian processes. However, it is quite challenging to evaluate the relative importance of eolian and fluvial processes. Given the complexity and uncertainty in the interpretation of the raw grain size data, we derived $d_{50}$ and $C_{u}$ to indicate changes in depositional environmental conditions such as energy strength and energy constancy (wind speed and flow velocity), respectively.

Sediments from San Luis Lake are composed of clays, silts, sands and, to less extent, pebbles, with an average $d_{50}$ of $0.4 \mathrm{~mm}$ (Fig. 9e). Values of $d_{50}$ were relatively low during many dry intervals such as the Big Dry, B/A,
$\mathrm{EH}$, and LH. The low values of $d_{50}$ were likely attributed to increases in eolian flux and/or decreases in fluvial loading when dry conditions persisted in the basin. A lowering of groundwater table would promote the eolian process in this basin (Madole et al., 2008). Values of $d_{50}$ were relatively high during wet periods such as the Big Wet, YD, $\mathrm{PB}$, and $\mathrm{MH}$. It is worth noting that values of $d_{50}$ are exceptionally high during two intervals centered at 3.1 and $5.9 \mathrm{ka}$, suggesting the dominance of fluvial loading when the climate was extremely wet. Whereas low values of $d_{50}$ were induced by reduced fluvial loading and/or increased eolian flux during dry conditions, high values of $d_{50}$ of sediments in San Luis Lake were more likely caused by enhanced fluvial loading during extremely wet conditions. A period of low $d_{50}$ values at the beginning of the $\mathrm{MH}$, for example, might be associated with reduced fluvial inputs due to an increase in effective moisture and an expansion in lake surface area.

Values of $C_{u}$ may be indicative of sediment sorting and associated energy constancy of the environment when sediments deposited. A sediment sample with a $C_{u}$ less than 4 is considered as well-sorted while a sample with a $C_{u}$ greater than 6 is considered as poorly-sorted (Fetter, 2000). Most of the sediment samples from San Luis Lake have a $C_{u}$ close to or less than 6 (Fig. 9f). This indicates that most of the sediments in the lake are not well sorted, suggesting a rather variable or energetic depositional environment with a limited energy constancy for most of the time over the last $16.5 \mathrm{ka}$. Two prominent excursions of high $C_{u}$ values during the mid-Holocene are likely attributed to enhanced fluvial processes.

Magnetic susceptibility, a measure of allochthonous magnetic materials from erosion of the watershed or deposition from a volcanic tephra (Dearing, 1999), is widely used to document changes in the sedimentary inputs to a lake or bog in the region (e.g., Cisneros-Dozal et al., 2010; Jimenez-Moreno et al., 2011). The magnetic susceptibility record from San Luis Lake shares some similar features of variability with the $C_{u}$ data (Fig. 9f, g). Values of magnetic susceptibility are relatively low in the early part of the record (prior to $6 \mathrm{ka}$ ). Our magnetic susceptibility record also displays two prominent excursions in the mid-Holocene though there is a small age offset between the $C_{u}$ and MS excursions. The cause of the age offset remains unknown.

\subsection{Late Glacial-Holocene transition (16.5-10.5 ka)}

The Late Glacial-Holocene transition (LGHT) represents the largest climatic and environmental change in the past $100 \mathrm{ka}$. As expressed in the $\delta^{18} \mathrm{O}$ variations of ice cores from Greenland (Svensson et al., 2008), the LGHT was featured with a series of millennial-scale climatic oscillations, such as the Heinrich cold event \#1 (H1; Bond et al., 1992), the B/A warming, the YD cooling, and the PB warming (Fig. 11). Our sediment record documented a detailed history of hydroclimate change in this region. First, our record documents that a rapid dry to wet transition occurred at the midpoint of the H1 or the Mystery Interval (MI), leading to an overflowing of San Luis Lake. The Big Wet to Big Dry transition is essentially concurrent, within the age uncertainty, with lake level fluctuations in Lake Estancia, New Mexico (Allen and Anderson, 2000) and Lake Lahontan, Nevada (Benson et al., 1990) (Fig. 11). Our results further attest to a large-scale two-phase hydrological response to the H1 event (Broecker et al., 2009; Broecker and Putnam, 2012). Second, dry conditions prevailed in the San Luis Lake basin during the B/A warm period. At high elevations, widespread tundra and parkland in the cold Big Wet period transitioned into open subalpine forest in the B/A warm dry period, based on pollen and charcoal data from Lily Pond in central Colorado (Briles et al., 2012). Pluvial lakes in the American Southwest (e.g., Lake Lahontan, Lake Estancia and Lake Cochise) lowered or desiccated during this period (Waters, 1989; Benson et al., 1990; Allen and Anderson, 2000). Third, the basin was wetter due to increased winter precipitation during the YD interval. Finally, the LGTH was concluded by a rapid change in precipitation regimes, i.e., from a winter-dominated 


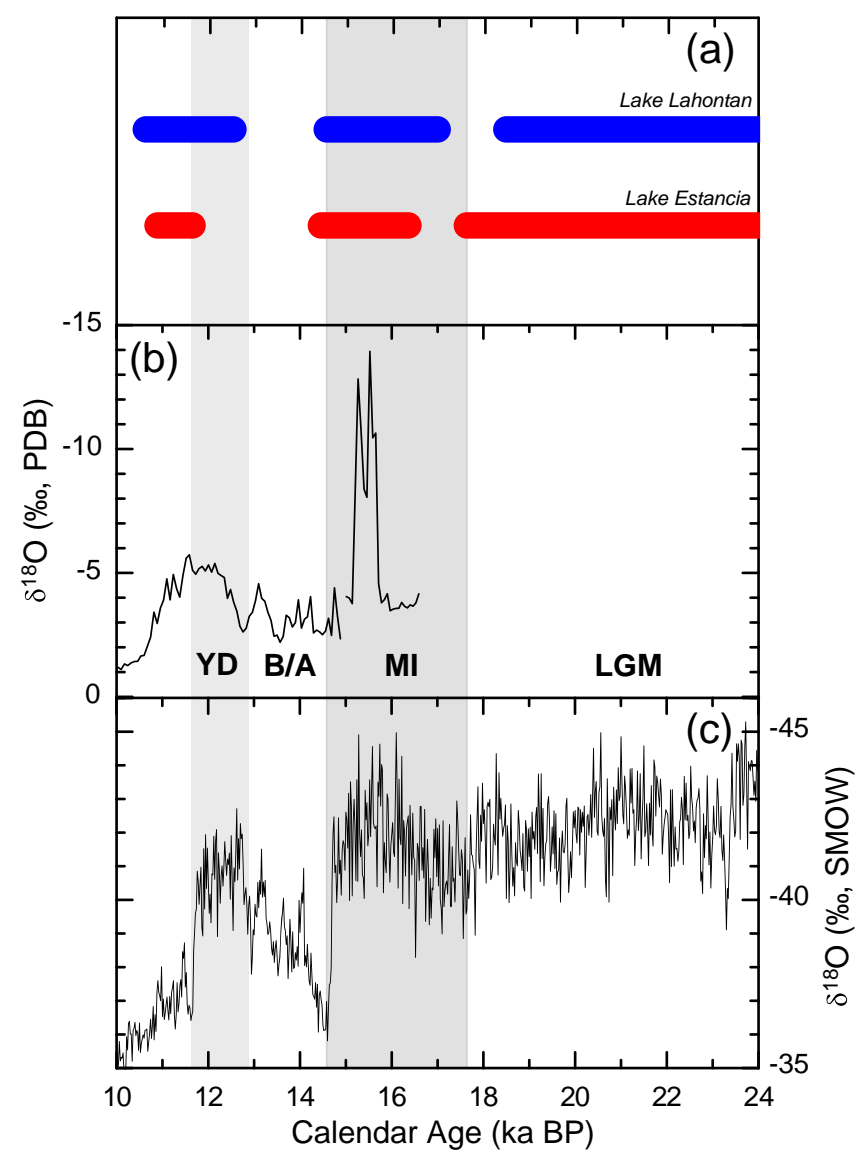

Fig. 11. Comparison of (a) the lake-level reconstructions of Lake Lahontan and Lake Estancia (Benson et al., 1990; Allen and Anderson, 2000), (b) the $\delta^{18} 0$ record from San Luis Lake, and (c) the ice $\delta^{18} \mathrm{O}$ record from Greenland (Svensson et al., 2008). Filled horizontal bars denote intervals with highstands.

moisture regime in the YD period shifting to a greater summer precipitation in the PB interval.

The $\delta^{18} \mathrm{O}$ record of San Luis Lake shows some degree of similarity with the isotopic record of ice cores from Greenland (Fig. 11). Particularly, there was a $5 \%$ increase in $\delta^{18} \mathrm{O}$ during the $\mathrm{PB}$ in the two records. We interpret this as representing a $5 \%$ increase in $\delta^{18} \mathrm{O}$ of precipitation in the basin because the lake system appeared to be under hydrologic steady-state conditions. This interpretation is consistent with the Fort Stanton speleothem data that indicate a $6 \%$ range of variability during the Pleistocene-Holocene transition (Asmerom et al., 2010). Similarly, we attribute one half of the observed increase in $\delta^{18} \mathrm{O}$ to temperature change and the other half to changes in precipitation seasonality. If the Dansgaard (1964) relationship between air temperature and $\delta^{18} \mathrm{O}$ of precipitation $\left(0.5 \%\right.$ o per $\left.{ }^{\circ} \mathrm{C}\right)$ is applicable to this region, it can be readily inferred that a $5{ }^{\circ} \mathrm{C}$ warming occurred during the final stage of the LGHT. This contrasts the treeline-based estimate made by Reasoner and Jodry (2000) but is in line with the moderate temperature change inferred from noble gases in groundwater in Texas (Stute et al., 1992). Further, using a simple binary mixing model (Yuan and Miyamoto, 2008; Asmerom et al., 2010), we inferred that a 0.25 fractional increase in summer rainfall is required to account for the half of $5 \%$ increase during the PB warming interval. We attributed the changes in precipitation seasonality to enhanced monsoonal circulation, a conclusion in agreement with the plant macrofossil data from packrat middens in the Mojave Desert which provided evidence for increased temperature and summer rainfall during this interval (Spaulding and Graumlich, 1986).

\subsection{Holocene hydroclimate variability}

The Holocene climate is characterized by gradual changes in the $\mathrm{EH}$ and $\mathrm{LH}$ and rapid fluctuations in the $\mathrm{MH}$, comparable to the $\delta^{18} \mathrm{O}$ records from two alpine lakes in northern Colorado (Fig. 12). All of the three lake-based studies exhibit a long-term decreasing trend of $\delta^{18} \mathrm{O}$ from the $\mathrm{EH}$ to $\mathrm{MH}$, indicating a reduction in summer precipitation from a weakening of the NAM through the Holocene (Friedman et al., 1988). The gradual shifting trend of precipitation seasonality was interrupted by an abrupt $2.0 \%$ o decrease in $\delta^{18} \mathrm{O}$ and $\delta^{13} \mathrm{C}$ at $6.7 \mathrm{ka}$, a $5 \%$ decrease in TIC, a 0.3 increase in $\mathrm{Mg} / \mathrm{Ca}$, and a $0.4 \mathrm{~mm}$ decrease in $d_{50}$, signaling a rapid expansion of the lake from enhanced winter precipitation at the beginning of the $\mathrm{MH}$. The inferred change in effective moisture corresponded to an expansion of the spruce zone in the La Plata Mountains in southwestern Colorado (Petersen, 1988) and a downslope movement of subalpine forest in central Colorado (Briles et al., 2012). The San Luis Valley was overall wet in the MH but punctuated by several centennial to millennial-scale dry episodes. San Luis Lake overflowed again during an exceedingly wet period centered at $3 \mathrm{ka}$, nearly concurrent with the pronounced negative excursions of $\delta^{18} \mathrm{O}$ in Bison and Yellow Lakes (Fig. 12). The timing of this pluvial event or so called Neopluvial (Currey, 1990) is consistent with reconstructions of paleolakes in the Great Basin and elsewhere in the American Southwest, e.g., the highest Holocene stand of Mono Lake (California) occurred 3.7 ka (Stine, 1990), and high stands of Lake Cochise (Eastern Arizona) at 3-4 ka (Waters, 1989).

The most striking feature of the three lake $\delta^{18} \mathrm{O}$ records from Colorado is a noticeable shift in the mode of isotopic variability from the $\mathrm{MH}$ to $\mathrm{LH}$ (Fig. 12). Variability in $\delta^{18} \mathrm{O}$ of San Luis Lake reduced considerably after the Neopluvial, whereas variability in $\delta^{18} \mathrm{O}$ of Bison and Yellow lakes increased concurrently. Such a marked shift in isotopic variability across Colorado suggests that a northward displacement of atmospheric circulations (i.e., the PJS) may have occurred about 3 ka, leading to a sizeable reduction in precipitation and stream inflows into San Luis Lake. As a result, San Luis Lake underwent a rapid $10 \%$ increase in $\delta^{18} \mathrm{O}$, suggesting a hydrological closure of the lake system. The timing of this change is consistent with a rapid contraction of the spruce zone in the La Plata Mountains (Petersen, 1988). The ratio of summer to winter precipitation increased steadily until it reached its maximum during the Medieval Climate Anomaly, as indicated by an increasing trend of $\delta^{18} \mathrm{O}$. Although we cannot completely rule out a possible resurge of monsoonal rainfall, evidence of widespread dry lakes across the desert American Southwest indicates that the observed increases in $\delta^{18} \mathrm{O}$ during the LH were induced largely by decreases in winter precipitation instead of increased monsoonal rainfall. Lastly, San Luis Lake received slightly more winter precipitation, as indicated by a pronounced negative isotopic excursion during the Little Ice Age. Our interpretation of a dry LH climate is broadly consistent with vegetation data which indicate the prevalence of more arid conditions in much of the American southwest (Van Devender, 1987; Thompson et al., 1993).

\subsection{Linkages to climate change in distant regions}

To develop a context of climate variability in the southern Rocky Mountains, we compared our $\delta^{18} \mathrm{O}$ record with the $\delta^{18} \mathrm{O}$ record of Laguna Pumacocha in the Peruvian Andes (Bird et al., 2011), the \%Ti record of the Cariaco Basin (Haug et al., 2001), and the $\delta^{18} \mathrm{O}$ record of Greenland ice cores (Svensson et al., 2008) (Fig. 13). First, our sediment chronology is consistent with the ice core record from Greenland, particularly during the LGHT. Second, our $\delta^{18} \mathrm{O}$ record exhibits some similar features of hydrologic variability with the Cariaco Basin data. For example, $\delta^{18} \mathrm{O}$ of San Luis Lake and \%Ti of the Cariaco Basin decreased in the YD cold interval and subsequently increased in the PB warm interval, followed by a concurrent long-term decreasing trend in the Holocene before it was interrupted about $3 \mathrm{ka}$. Third, our record contains some shared features with the Laguna Pumacocha data. For example, the two lakes experienced 


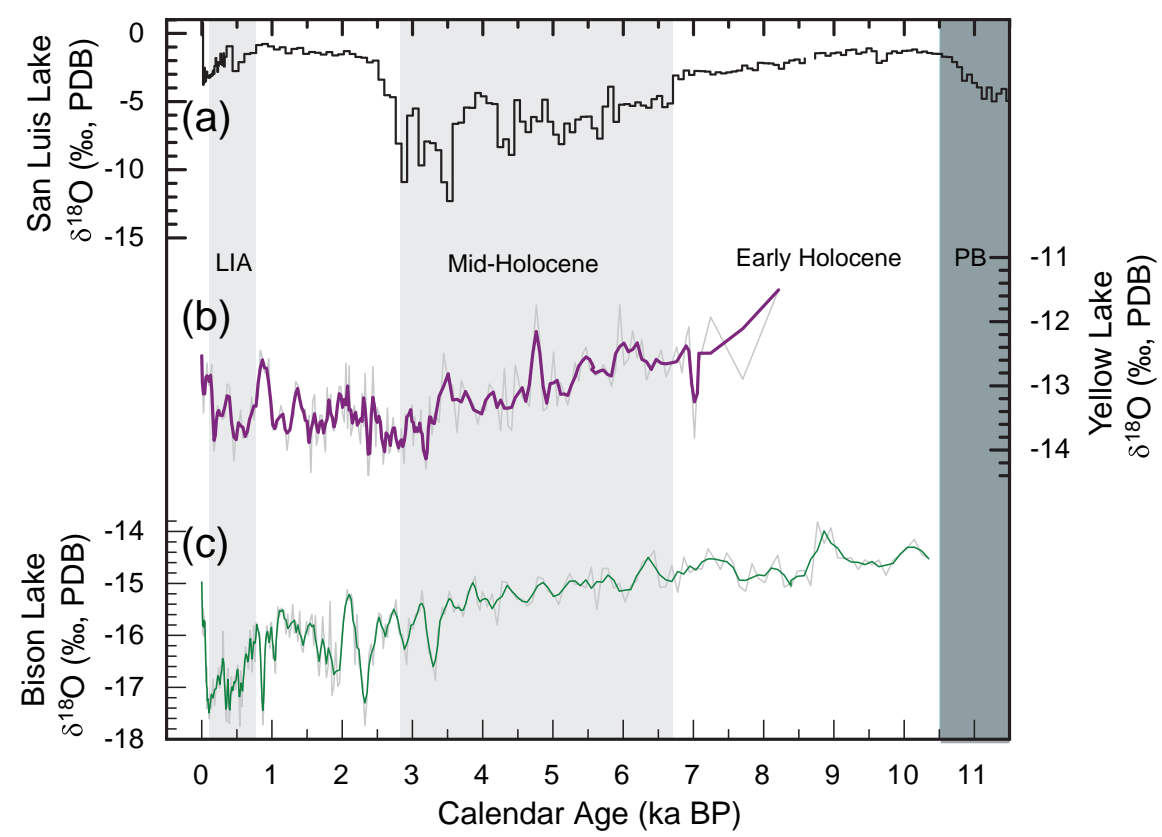

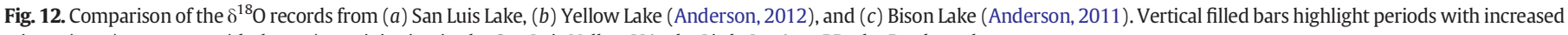
winter (gray) or summer (dark gray) precipitation in the San Luis Valley. LIA: the Little Ice Age; PB: the Pre-boreal.
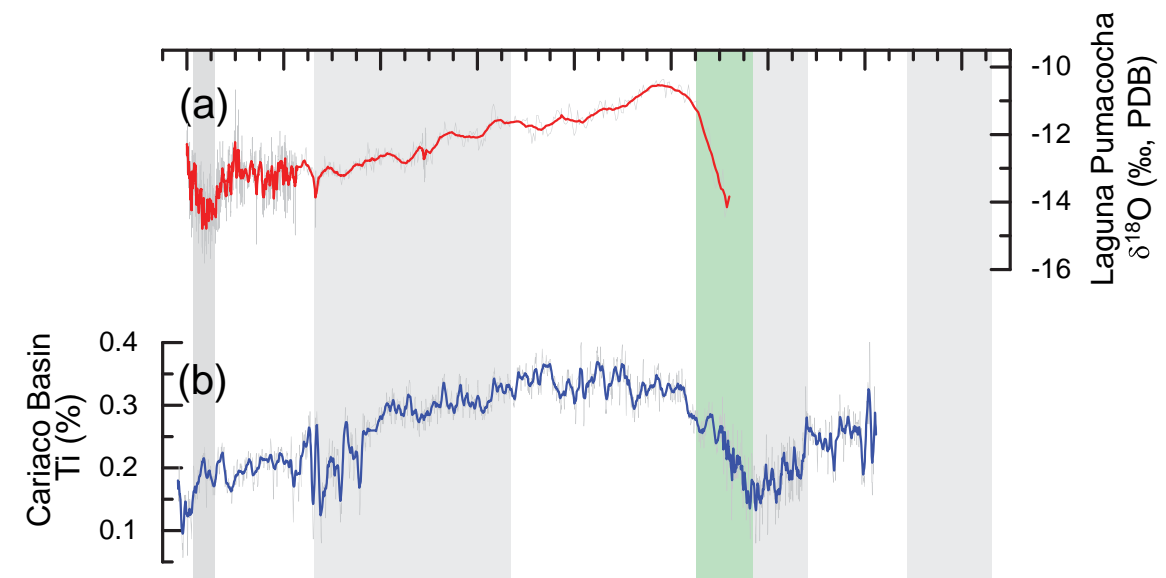

(c)

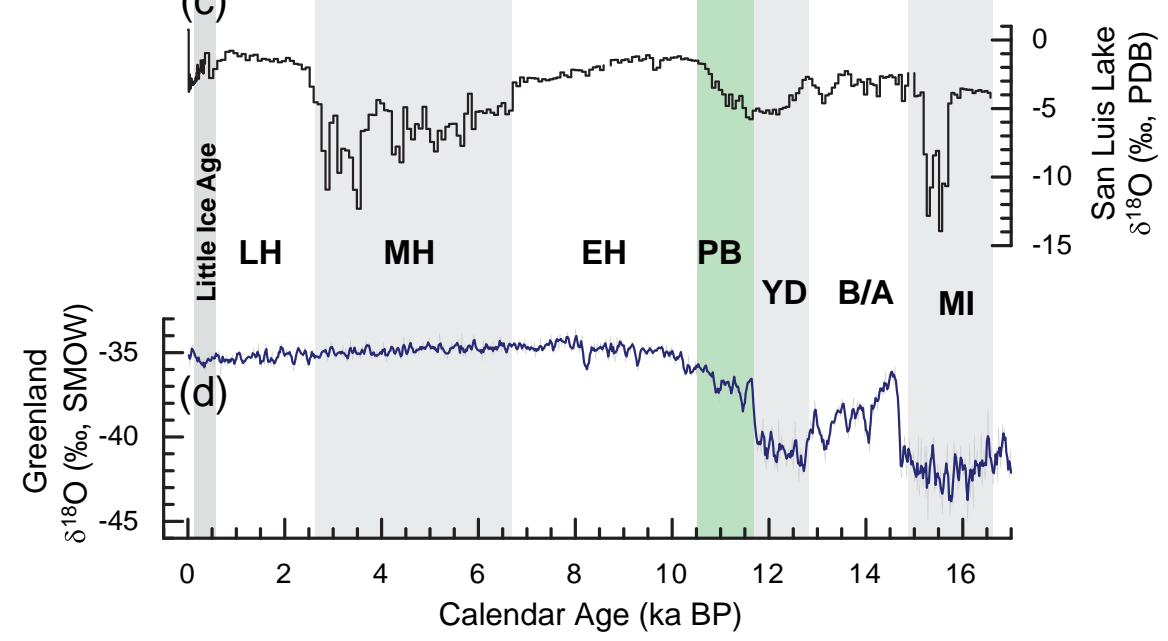

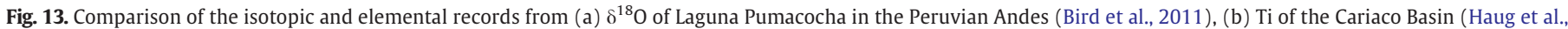

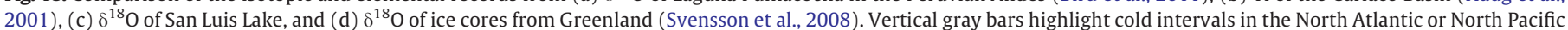

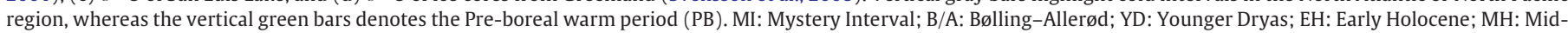
Holocene; LH: Late Holocene. 
a 4-5\% increase in $\delta^{18} \mathrm{O}$ during the PB warm period and subsequently a long-term decreasing trend in the Holocene. The decreasing trend of $\delta^{18} \mathrm{O}$ in San Luis Lake reflects a long-term weakening of the NAM in the Holocene while the decreasing trend of $\delta^{18} \mathrm{O}$ in Laguna Pumacocha represents a long-term strengthening of the South American monsoon (Bird et al., 2011). This antiphased relationship between the two monsoons over the time can be best explained by southward migration of the ITCZ through the Holocene.

Like other lakes in the American Southwest, San Luis Lake underwent rapid and large changes in climate during the LGHT. These changes were previously attributed to alternations between stadial and interstadial conditions in the North Atlantic region (Benson et al., 1997). But little is known about the link between the two regions. Today, changes in the mid-latitude and subtropical atmospheric circulations are important features that affect hydroclimate in the American Southwest as it usually receives more precipitation from winter storms when the PJS is displaced southward and vice versa (Redmond and Koch, 1991). Moreover, onset of the NAM is associated with the retreat of the Westerlies and the advance of the subtropical high-pressure ridge over the region (Sheppard et al., 2002). Our record indicated that the winter (summer) storms were stronger (weaker) during the cold periods (e.g., the YD and LIA) and weaker (stronger) during the warm periods (e.g., the $\mathrm{PB}$ and $\mathrm{B} / \mathrm{A}$ ). This provides evidence that on millennial time scales the changes in the ITCZ and PJS are globally orchestrated.

Nevertheless, the concept of a globally-orchestrated atmospheric modulation has exceptions. First, San Luis Lake underwent a drastic hydroclimatic change during the $\mathrm{H} 1$ cold event. Broecker and Putnam (2012) compiled a range of paleoclimate records of paleolake levels, the Asian monsoons, and Antarctic $\mathrm{CO}_{2}, \delta^{13} \mathrm{C}$, and dust rain, showing that a globally significant hydrologic change occurred at the midpoint of the $\mathrm{H} 1$ event. Our results from San Luis Lake support the existence of such a large-scale hydrologic change in the middle of the MI. Broecker and Putnam (2012) proposed three driving mechanisms to account for the observed change, namely a sea-ice expansion in the North Atlantic, an orographic influence of Laurentide ice sheet on the PJS, and a possible change in the Southern Ocean. Here, we put forward an idea that a change in the North Pacific may be sufficient to explain this dilemma. A cooling of the North Pacific from a reduction in poleward heat advection may have displaced the thermal equator, PJS and ITCZ southward, leading to the rise of lake levels in the American Southwest. This idea is supported by evidence that the rise of paleolake levels in the American Southwest coincided with a rapid cooling of the North Pacific at the midpoint of the MI, as revealed by the dinocyst SST record from the Northeast Pacific (de Vernal and Pedersen, 1997; Okazaki et al., 2010).

Second, the Neopluvial episode seen in our San Luis Lake and other lake-level reconstructions across the American Southwest is extraordinary (Fig. 14). Enzel et al. (1989) documented the existence of such a pluvial event in the Mojave Desert between 4 and 3 ka and suggested a climatic link to winter atmospheric conditions over the North Pacific. Recently, Anderson (2011) noted that variability in $\delta^{18} \mathrm{O}$ of Bison Lake increased dramatically after $3.5 \mathrm{ka}$ and attributed the inferred changes in hydroclimate to the coupled ocean-atmosphere system such as ENSO. However, it is debatable whether the mechanisms that operate at interannual time scales are applicable to climatic anomalies over the millennial and longer time scales (Wagner et al., 2010). It is worth noting that there was a corresponding increase in the variability of \% $\mathrm{Ti}$ in the Cariaco basin about $3.8 \mathrm{ka}$ but no such change in Laguna

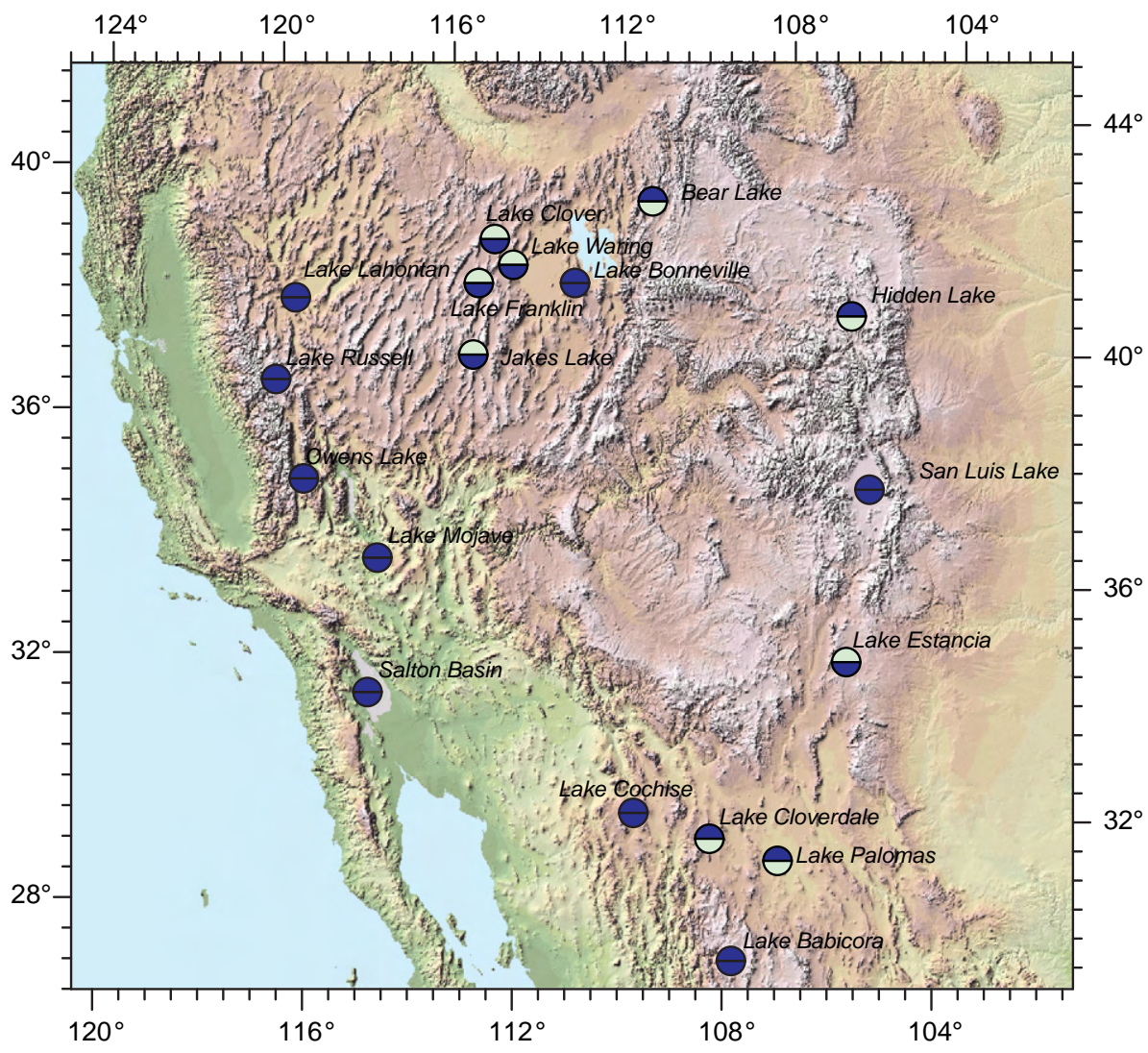

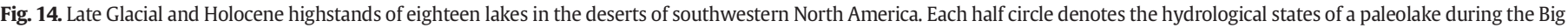

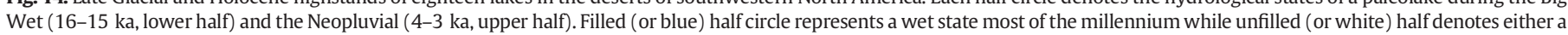
dry state or no data (see Table S1). Base map was created using an online mapper at nationalatlas.gov. 
Pumacocha, highlighting the role of the North Pacific in regulating precipitation regimes over the southern Rocky Mountains and adjacent regions. In fact, the $\mathrm{MH}$ pluvial episode started as early as $6.8 \mathrm{ka}$, nearly coinciding with the onset of Neoglaciation, e.g., the Garibaldi Phase from 6.9 to $5.6 \mathrm{ka}$ in western Canada (Clague et al., 2009), and a Holocene cooling of the North Pacific from an alkenone SST reconstruction off the northern California coast (Barron et al., 2003).

Lastly, the Big Wet and Neopluvial highstands shared some interesting features. First, the two pluvial events were widespread and had a similar spatial coverage in the desert southwest (Fig. 14). Second, the two extreme wet episodes corresponded well with a cooling of the North Pacific and a southward displacement of the PJS and ITCZ. Third, the two events occurred in periods without a significant change in the North Atlantic region. Also, we noted that the two episodes occurred under completely different background climate states (glacial vs. interglacial) and that, based on SSTs reconstructions (Barron et al., 2003; Okazaki et al., 2010), the cooling of the North Pacific during the H1 was much greater than that during the Neopluvial. Collectively, the results of this work along with others provide evidence for a strong climatic link between the North Pacific and southwestern North America on millennial and longer time scales (Enzel et al., 1989; Herbert et al., 2001; Yuan et al., 2004).

\section{Conclusions}

Sediments from San Luis Lake were recovered and analyzed to indicate climatic and environmental changes in the southern Rocky Mountains over the last $16.5 \mathrm{ka}$. San Luis Lake was hydrologically closed most of the time but overflowed during the Big Wet and the Neopluvial intervals. Our results are broadly consistent with existing lake-level reconstructions, paleobotanical data and other paleoclimate records from the southern Rocky Mountains and adjacent regions. Over the course of the last glacial termination, San Luis Lake underwent a series of millennial-scale dry/wet oscillations such as the Big Dry, the Big Wet, the B/A dry, and the YD wet, corresponding to interstadial/ stadial alternations in the high-latitude North Hemisphere. There was a $5 \%$ increase in $\delta^{18} \mathrm{O}$ of San Luis Lake during the PB interval, close to that seen in the Greenland ice core and the Fort Stanton speleothem $\delta^{18} \mathrm{O}$ records. In agreement with other Colorado lake records, our record from San Luis Lake exhibits a long-term decreasing trend of $\delta^{18} \mathrm{O}$ in the Holocene, indicating a greater summer moisture regime in the $\mathrm{EH}$ transitioning to a winter-dominated precipitation regime in the MH.

Our sediment record from San Luis Lake documents a detailed history of Late-Glacial and Holocene changes in hydroclimate which allows us to compare climatic records from distant regions to gain novel insights into the major mechanisms for millennial-scale oscillations in the region. San Luis Lake underwent a rapid dry to wet transition at the midpoint of the MI, coinciding with a cooling of the Northeast Pacific. Our data indicate that the NAM waxed in the PB and waned in the $\mathrm{EH}$, corresponding to the latitudinal shifts of the ITCZ. The San Luis Valley was relatively dry during the $\mathrm{EH}$ and became wet but quite variable during the $\mathrm{MH}$. Onset of the wet $\mathrm{MH}$ period was nearly concurrent with the advance of the Neoglacial in western Canada and a cooling of the North Pacific as indicated by the SSTs record from coastal northern California. Although hydroclimatic oscillations are broadly tied to conditions in the North Atlantic region, the wettest episodes of the southern Rocky Mountains and elsewhere in the American Southwest (i.e., the Big Wet and Neopluvial) are more closely linked to features in the North Pacific. Our results indicate that the changes in hydroclimate are determined primarily by features of large-scale atmospheric circulations over the region. Cold/warm oscillations in the high-latitude Northern Hemisphere change the mean position of the low-latitude features such as the ITCZ and the thermal equator, which, in turn, modulate Pacific winter storms and summer monsoonal circulations.

\section{Acknowledgments}

We acknowledge J. Beeton and J. Quellos for their assistance with the field work and M. Albert and S. Howe for their assistance with the lab work. We also thank B. Saylor and B. Linsley who made their lab facilities available for us. This work was supported by a research award (EAR-0902895) from the U.S. National Science Foundation and a small grant of Faculty Research Development from Cleveland State University. This manuscript especially benefited from the critical comments by T. Corrège and two anonymous reviewers.

\section{Appendix A. Supplementary data}

Supplementary data to this article can be found online at http://dx. doi.org/10.1016/j.palaeo.2013.09.016.

\section{References}

Allen, B.D., Anderson, R.Y., 2000. A continuous, high-resolution record of late Pleistocene climate variability from the Estancia basin, New Mexico. Geol. Soc. Am. Bull. 112 1444-1458.

Anderson, R.S., 1993. A 35,000 year vegetation and climate history from Potato Lake, Mogollon Rim, Arizona. Quat. Res. 40, 351-359.

Anderson, R.Y., 2001. Rapid changes in Late Pleistocene precipitation and stream discharge determined from medium- and coarse-grained sediment in saline lakes. Glob. Planet Chang. 28, 73-83.

Anderson, L., 2011. Holocene record of precipitation seasonality from lake calcite delta O-18 in the central Rocky Mountains, United States. Geology 39, 211-214.

Anderson, L., 2012. Rocky Mountain hydroclimate: Holocene variability and the role of insolation, ENSO, and the North American Monsoon. Glob. Planet. Chang. 92-93, 198-208.

Anderson, R.S., Jass, R.B., Toney, J.L., Allen, C.D., Cisneros-Dozal, L.M., Hess, M., Heikoop, J. Fessenden, J., 2008. Development of the mixed conifer forest in northern New Mexico and its relationship to Holocene environmental change. Quat. Res. 69, 263-275.

Appleby, P.G., Oldfield, F., 1978. The calculation of lead-210 dates assuming a constant rate of supply of unsupported ${ }^{210} \mathrm{~Pb}$ to the sediment. Catena $5,1-8$.

Asmerom, Y., Polyak, V., Burns, S., Rassmussen, J., 2007. Solar forcing of Holocene climate: new insights from a speleothem record, southwestern United States. Geology 35, 1-4

Asmerom, Y., Polyak, V.J., Burns, S.J., 2010. Variable winter moisture in the southwestern United States linked to rapid glacial climate shifts. Nat. Geosci. 3, 114-117.

Barron, J.A., Heusser, L., Herbert, T., Lyle, M., 2003. High-resolution climatic evolution of coastal northern California during the past 16,000 years. Paleoceanography $18,1020$.

Barron, J.A., Metcalfe, S., Addison, J.A., 2012. Response of the North American Monsoon to regional changes in ocean surface temperature. Paleoceanography 27, 1-17.

Benson, L., Paillet, F., 2002. HIBAL: a hydrologic-isotopic-balance model for application to paleolake systems. Quat. Sci. Rev. 21, 1521-1539.

Benson, L.V., Currey, D.R., Dorn, R.I., Lajoie, K.R., Oviatt, C.G., Robinson, S.W., Smith, G.I Stine, S., 1990. Chronology of expansion and contraction of four great Basin lake systems during the past 35,000 years. Palaeogeogr. Palaeoclimatol. Palaeoecol. 78, 241-286.

Benson, L.V., Meyers, P.A., Spencer, R.J., 1991. Change in the size of Walker Lake during the past 5000 years. Palaeogeogr. Palaeoclimatol. Palaeoecol. 81, 189-214.

Benson, L., White, L.D., Rye, R., 1996. Carbonate deposition, Pyramid Lake Subbasin, Nevada: 4. Comparison of the stable isotope values of carbonate deposits (tufas) and the Lahontan lake-level record. Palaeogeogr. Palaeoclimatol. Palaeoecol. 122, 45-76.

Benson, L., Burdett, J., Lund, S., Kashgarian, M., Mensing, S., 1997. Nearly synchronous climate change in the Northern Hemisphere during the last glacial termination. Nature 388, 263-265.

Benson, L., Kashgarian, M., Rye, R., Lund, S., Paillet, F., Smoot, J., Kester, C., Mensing, S. Meko, D., Lindstrom, S., 2002. Holocene multidecadal and multicentennial droughts affecting Northern California and Nevada. Quat. Sci. Rev. 21, 659-682.

Betancourt, J.L., Rylander, K.A., Penalba, C., McVickar, J.L., 2001. Late Quaternary vegetation history of Rough Canyon, south-central New Mexico, USA. Palaeogeogr. Palaeoclimatol. Palaeoecol. 165, 71-95.

Bird, B.W., Abbott, M.B., Rodbell, D.T., Vuille, M., 2011. Holocene tropical South American hydroclimate revealed from a decadally resolved lake sediment $\delta^{18} \mathrm{O}$ record. Earth Planet. Sci. Lett. 310, 192-202.

Bond, G., Heinrich, H., Broecker, W. Labeyrie, L., McManus, J., Andrews, J., Huon, S Jantschik, R., Clasen, S., Simet, C., Tedesco, K., Klas, M., Bonani, G., Ivy, S., 1992. Evidence for massive discharges of icebergs into the North Atlantic ocean during the last glacial period. Nature 360, 245-249.

Briles, C.E., Whitlock, C., Meltzer, D.J., 2012. Last glacial-interglacial environments in the southern Rocky Mountains, USA and implications for Younger Dryas-age human occupation. Quat. Res. 77, 96-103.

Brister, B.S., Gries, R.R., 1994. Tertiary stratigraphy and tectonic development of the Alamosa basin (northern San Luis Basin), Rio Grande rift, south-central Colorado. Geol. Soc. Am. Spec. Pap. 291, 39-58.

Broecker, W., Putnam, A.E., 2012. How did the hydrologic cycle respond to the two-phase mystery interval? Quat. Sci. Rev. 57, 17-25. 
Broecker, W.S., McGee, D., Adams, K.D., Cheng, H., Edwards, R.L., Oviatt, C.G., Quade, J, 2009. A Great Basin-wide dry episode during the first half of the Mystery Interval? Quat. Sci. Rev. 28, 2557-2563.

Bui, E.N., Mazzullo, J.M., Wilding, L.P., 1989. Using quartz grain size and shape analysis to distinguish between aeolian and fluvial deposits in the Dallol Bosso of Niger (West Africa). Earth Surf. Process. Landforms 14, 157-166.

Castro, C.L., McKee, T.B., Pielke, R.A., 2001. The relationship of the North American Monsoon to tropical and North Pacific sea surface temperatures as revealed by observationa analyses. J. Clim. 14, 4449-4473.

Cayan, D.R., 1996. Interannual climatic variability and snowpack in the western United States. J. Clim. 9, 928-948.

Chivas, A.R., Deckker, P., Shelley, J.M.G., 1986. Magnesium and strontium in non-marine ostracod shells as indicators of palaeosalinity and palaeotemperature. Hydrobiologia $143,135-142$

Cisneros-Dozal, L.M., Heikoop, J.M., Fessenden, J., Anderson, R.S., Meyers, P.A., Allen, C.D Hess, M., Larson, T., Perkins, G., Rearick, M., 2010. A 15,000-year record of climate change in northern New Mexico, USA, inferred from isotopic and elemental contents of bog sediments. J. Quat. Sci. 25, 1001-1007.

Clague, J.J., Menounos, B., Osborn, G., Luckman, B.H., Koch, J., 2009. Nomenclature and resolution in Holocene glacial chronologies. Quat. Sci. Rev. 28, 2231-2238.

Conroy, J.L., Overpeck, J.T., Cole, J.E., Shanahan, T.M., Steinitz-Kannan, M., 2008. Holocene changes in eastern tropical Pacific climate inferred from a Galapagos lake sediment record. Quat. Sci. Rev. 27, 1166-1180.

Cordell, L., 1978. Regional geophysical setting of the Rio Grande rift. Geol. Soc. Am. Bull. $89,1073-1090$

Costigan, K.R., Bossert, J.E., Langley, D.L., 2000. Atmospheric/hydrologic models for the Rio Grande Basin: simulations of precipitation variability. Glob. Planet. Chang. 25, 83-110.

Currey, D.R., 1990. Quaternary palaeolakes in the evolution of semidesert basins, with special emphasis on Lake Bonneville and the Great Basin, U.S.A. Palaeogeogr. Palaeoclimatol. Palaeoecol. 76, 189-214.

Dansgaard, W., 1964. Stable isotopes in precipitation. Tellus 16, 436-468.

De Lanois, J.L., Climatic change during the late Holocene from a south central Colorado lake. (1993) unpulb. M.S. thesis, University of Arizona Tucson, AZ.

de Vernal, A., Pedersen, T.F., 1997. Micropaleontology and palynology of core PAR87A-10: A 23,000 year record of paleoenvironmental changes in the Gulf of Alaska, northeast North Pacific. Paleoceanography 12, 821-830.

Dearing, J.A., 1999. Holocene environmental change from magnetic proxies in lake sediments. In: Maher, B.A., Thompson, R. (Eds.), Quaternary Climates, Environments and Magnetism. Cambridge University Press, pp. 231-278.

Doesken, N.J., McKee, T.B., 1989. The incredible climate of the San Luis Valley. In: Harmon, E.J. (Ed.), Water in the Valley, A 1989 Perspective on Water Supplies, Issues and Solutions in the San Luis Valley. Colo. Groundwater Assoc., Colorado, pp. 80-98.

Drummond, C.N., Patterson, W.P., Walker, J.C.G., 1995. Climate forcing of carbon-oxygen isotopic covariance in temperate-region marl lakes. Geology 23, 1031-1034.

Ellis, A., Barton, N., 2012. Characterizing the North Pacific jet stream for understanding historical variability in Western United States winter precipitation. Phys. Geogr. 33 105-128.

Emery, P.A., 1979. Geohydrology of the San Luis Valley, Colorado, USA, The Hydrology of Areas of Low Precipitation. IAHS-AISH Publ. No. 128. 297-305.

Engleman, E.E., Jackson, L.L., Norton, D.R., 1985. Determination of carbonate carbon in geological materials by coulometric titration. Chem. Geol. 53, 125-128.

Enzel, Y., Cayan, D.R., Anderson, R.Y., Wells, S.G., 1989. Atmospheric circulation during Holocene lake stands in the Mojave Desert: evidence of regional climate change. Nature 341, 44-47.

Fall, P.L., 1997. Timberline fluctuations and late Quaternary paleoclimates in the Southern Rocky Mountains, Colorado. Geol. Soc. Am. Bull. 109, 1306-1320.

Fetter, C.W., 2000. Applied Hydrogeology. Prentice Hall, Upper Saddle River, New Jersey, USA.

Friedman, I., Carrara, P., Gleason, J., 1988. Isotopic evidence of Holocene climatic change in the San Juan Mountains, Colorado. Quat. Res. 30, 350-353.

Gat, J.R., 1995. Stable isotopes of fresh and saline lakes. In: Lerman, A., Imboden, D., Gat, J. (Eds.), Physics and Chemistry of Lakes. Springer-Verlag, NJ, pp. 139-165.

Gosselin, D.C. 1997. Major-ion chemistry of compositionally diverse lakes, Western Nebraska, U.S.A.: implications for paleoclimatic interpretations. J. Paleolimnol. 17, 33-49.

Haug, G.H., Hughen, K.A., Sigman, D.M., Peterson, L.C., Rohl, U., 2001. Southward migration of the intertropical convergence zone through the Holocene. Science 293, 1304-1308.

Held, I.M., Soden, B.J., 2006. Robust responses of the hydrological cycle to global warming. J. Clim. 19, 5686-5699.

Herbert, T.D., Schuffert, J.D., Andreasen, D., Heusser, L., Lyle, M., Ravelo, A.C., Stott, L.D. Herguera, J.C., 2001. Collapse of the California Current during glacial maxima linked to change on land. Science 293, 71-76.

Higgins, R.W., Mo, K.C., Yao, Y., 1998. Interannual variability of the US summer precipitation regime with emphasis on the southwestern monsoon. J. Clim. 11, 2582-2606.

Holmes, J.A., 1996. Trace-element and stable-isotope geochemistry of non-marine ostracod shells in Quaternary palaeoenvironmental reconstruction. J. Paleolimnol. 15, 223-235.

Jimenez-Moreno, G., Fawcett, P.J., Anderson, R.S., 2008. Millennial- and centennial-scale vegetation and climate changes during the late Pleistocene and Holocene from northern New Mexico (USA). Quat. Sci. Rev. 27, 1442-1452.

Jimenez-Moreno, G., Anderson, R.S., Atudorei, V., Toney, J.L., 2011. A high-resolution record of climate, vegetation, and fire in the mixed conifer forest of northern Colorado USA. Geol. Soc. Am. Bull. 123, 240-254.

Jodry, M.A., Stanford, D.J., 1996. Changing hydrologic regimes and prehistoric landscape use in the northern San Luis Valley, Colorado. In: Thompson, R.A., Hudson, M.R.
Pillmore, C.L. (Eds.), Geologic Excursions to the Rocky Mountains and Beyond. U.S. Geological Survey, Denver, CO, p. 11

Karl, T.R., Melillo, J.M., Peterson, T.C., 2009. Global Climate Change Impacts in the United States. Cambridge University Press, New York, NY 196.

Keeling, C.D., 1961. The concentration and isotopic abundances of carbon dioxide in rural and marine air. Geochim. Cosmochim. Acta 24, 277-298.

Krider, P.R., 1998. Paleoclimatic significance of Late Quaternary lacustrine and alluvial stratigraphy, Animas Valley, New Mexico. Quat. Res. 50, 283-289.

Leng, M.J., Marshall, J.D., 2004. Palaeoclimate interpretation of stable isotope data from lake sediment archives. Quat. Sci. Rev. 23, 811-831.

Li, H.C., Ku, T.L., 1997. $\delta^{13} \mathrm{C}-\delta^{18} \mathrm{O}$ covariance as a paleohydrological indicator for closedbasin lakes. Palaeogeogr. Palaeoclimatol. Palaeoecol. 133, 69-80.

Li, H.C., Ku, T.L., Stott, L.D., Anderson, R.F., 1997. Stable isotope studies on Mono Lake (California). $1 \delta^{18} \mathrm{O}$ in lake sediments as proxy for climatic change during the last 150 years. Limnol. Oceanogr. 42, 230-238.

Li, H.C., Xu, X.M., Ku, T.L., You, C.F., Buchheim, H.P., Peters, R., 2008. Isotopic and geochemical evidence of palaeoclimate changes in Salton Basin, California, during the past 20 kyr: 1. delta O-18 and delta C-13 records in Lake Tufa deposits. Palaeogeogr. Palaeoclimatol. Palaeoecol. 259, 182-197.

Machette, M.N., Marchetti, D.W., Thompson, R.A., 2007. Chapter G-Ancient Lake Alamosa and the Pliocene to Middle Pleistocene evolution of the Rio Grande. In: Machette, M.N., Coates, M.M., Johnson, M.L. (Eds.), 2007 Rocky Mountain Section Friends of the Pleistocene Field Trip-Quaternary Geology of the San Luis Basin of Colorado and New Mexico, September 7-9, 2007. U.S. Geological Survey Open-File Report 2007-1193, pp. 157-167.

Madole, R.F., Romig, J.H., Aleinikoff, J.N., VanSistine, D.P., Yacob, E.Y., 2008. On the origin and age of the Great Sand Dunes, Colorado. Geomorphology 99, 99-119.

Mayo, A.L., Davey, A., Christiansen, D., 2007. Groundwater flow patterns in the San Luis Valley, Colorado, USA revisited: an evaluation of solute and isotopic data. Hydrogeol. J. 15, 383-408.

Menking, K.M., Anderson, R.Y., 2003. Contributions of La Niña and El Niño to middle Holocene drought and late Holocene moisture in the American Southwest. Geology 31, 937-940.

Metcalfe, S.E., Bimpson, A., Courtice, A.J., O'Hara, S.L., Taylor, D.M., 1997. Climate change at the monsoon/Westerly boundary in Northern Mexico. J. Paleolimnol. $17,155-171$.

Mitchell, V.L., 1976. The regionalization of climate in the Western United States. J. Appl. Meteorol. 15, 920-927.

Ode, D.J., Tieszen, L.L., Lerman, J.C., 1980. The seasonal contribution of C3 and C4 plant species to primary production in a mixed prairie. Ecology 61, 1304-1311.

Okazaki, Y., Timmermann, A., Menviel, L., Harada, N., Abe-Ouchi, A., Chikamoto, M.O., Mouchet, A., Asahi, H., 2010. Deepwater formation in the North Pacific during the Last Glacial termination. Science 329, 200-204.

O'Neil, J.R., Clayton, R.N., Mayeda, T.K., 1969. Oxygen isotopic fractionation in divalent metal carbonates. J. Chem. Phys. 51, 5547-5558.

Petersen, K.L., 1988. In: Aikens, C.M., Arnold, S.S. (Eds.), Climate and the Dolores River Anasazi: A Paleoenvironmental Reconstruction from a 10,000-Year Pollen Record, La Plata Mountains, Southwestern Colorado. University of Utah, Salt Lake City, Utah, p. 152 .

Polyak, V.J., Asmerom, Y., 2005. Orbital control of long-term moisture in the southwestern USA. Geophys. Res. Lett. 32.

Quiring, S.M., Goodrich, G.B., 2008. Nature and causes of the 2002 to 2004 drought in the southwestern United States compared with the historic 1953 to 1957 drought. Clim. Res. 36, 41-52.

Reasoner, M.A., Jodry, M.A., 2000. Rapid response of alpine timberline vegetation to the Younger Dryas climate oscillation in the Colorado Rocky Mountains, USA. Geology $28,51-54$

Redmond, K.T., Koch, R.W., 1991. Surface climate and streamflow variability in the western United States and their relationship to large-scale circulation indices. Water Resour. Res. 27, 2381-2399.

Ritchie, J.C., McHenry, J.R., Gill, A.C., 1973. Dating recent reservoir sediments. Limnol. Oceanogr. 18, 254-263.

Rogers, K.L., Larson, E.E., Smith, G., Katzman, D., Smith, G.R., Cerling, T., Wang, Y., Baker, R.G., Lohmann, K.C. Repenning C.A., Patterson, P. Mackie, G, 1992. Pliocene and Pleistocene geologic and climatic evolution in the San Luis Valley of south-central Colorado. Palaeogeogr. Palaeoclimatol. Palaeoecol. 94, 55-86.

Romanek, C.S., Grossman, E.L., Morse, J.W., 1992. Carbon isotopic fractionation in synthetic aragonite and calcite: effects of temperature and precipitation rate. Geochim. Cosmochim. Acta 56, 419-430.

Shafer, D.S., 1989. The timing of late Quaternary monsoon precipitation maxima in the southwest United States. PhD Dissertation University of Arizona, Tuscon, Arizona, USA 234.

Shapley, M.D., Ito, E., Forester, R.M., 2010. Negative correlations between Mg:Ca and total dissolved solids in lakes: false aridity signals and decoupling mechanism for paleohydrologic proxies. Geology 38, 427-430.

Sheppard, P.R., Comrie, A.C., Packin, G.D., Angersbach, K., Hughes, M.K., 2002. The climate of the US Southwest. Clim. Res. 21, 219-238.

Shuman, B., Henderson, A.K., Colman, S.M., Stone, J.R., Fritz, S.C., Stevens, L.R., Power, M.J., Whitlock, C., 2009. Holocene lake-level trends in the Rocky Mountains, USA. Quat. Sci. Rev. 28, 1861-1879.

Siebenthal, C.E., 1910. Geology and water resources of the San Luis Valley, Colorado. U.S. Geological Survey Water Supply Paper, 240128.

Spaulding, W.G., 1991. A middle holocene vegetation record from the Mojave Desert of North America and its paleoclimatic significance. Quat. Res. 35, 427-437.

Spaulding, W.G., Graumlich, L.J., 1986. The last pluvial climatic episodes in the deserts of southwestern North America. Nature 320, 441-444. 
Stine, S., 1990. Late Holocene fluctuations of Mono Lake, eastern California. Palaeogeogr. Palaeoclimatol. Palaeoecol. 78, 333-381.

Street, F., Grove, A.T., 1979. Global maps of lake-level fluctuations since 30,000 yr B.P. Quat. Res. 12, 83-118.

Stuiver, M., 1975. Climate versus changes in ${ }^{13} \mathrm{C}$ content of the organic component of lake sediments during the Late Quaternary. Quat. Res. 5, 251-262.

Stuiver, M., Reimer, P.J., 1993. Extended ${ }^{14} \mathrm{C}$ data base and revised CALIB $3.0{ }^{14} \mathrm{C}$ age calibration program. Radiocarbon 35, 215-230.

Stute, M., Schlosser, P., Clark, J.F., Broecker, W.S., 1992. Paleotemperatures in the Southwestern United States derived from noble gases in ground water. Science 256, 1000-1003.

Svensson, A., Andersen, K.K., Bigler, M., Clausen, H.B., Dahl-Jensen, D., Davies, S.M., Johnsen, S.J., Muscheler, R., Parrenin, F., Rasmussen, S.O., Roethlisberger, R., Seierstad, I., Steffensen, J.P., Vinther, B.M., 2008. A 60,000 year Greenland stratigraphic ice core chronology. Clim. Past 4, 47-57.

Talbot, M., 1990. A review of the palaeohydrological interpretation of carbon and oxygen isotopic ratios in primary lacustrine carbonates. Chem. Geol. 80, 261-279.

Thompson, R.S., Anderson, K.H., 2000. Biomes of western North America at 18,000, 6000 and 0 C-14 yr BP reconstructed from pollen and packrat midden data. J. Biogeogr. 27, 555-584.

Thompson, T.A., Miller, C.S., Doss, P.K., Thompson, L.D.P., Baedke, S.J., 1991. Land-based vibracoring and vibracore analysis: tips, tricks and traps. Authority of the State of Indiana, Bloomington, IN, Occasional Paper, 5817.

Thompson, R.S., Whitlock, C., Bartlein, P.J., Harrison, S.P., Spaulding, W.G., 1993. Climatic changes in the western United States since 18,000 yr B.P. In: Wright Jr., H.E., Kutzbach, J.E., Webb III, T., Ruddiman, W.F., Street-Perrott, F.A., Bartlein, P.J. (Eds.), Global Climates Since the Last Glacial Maximum. University of Minnesota Press, pp. $468-513$.

Toney, J.L., Anderson, R.S., 2006. A postglacial palaeoecological record from the San Juan Mountains of Colorado USA: fire, climate and vegetation history. Holocene 16, 505-517.
Van Devender, T.R., 1977. Holocene woodlands in the southwestern deserts. Science 198 189-192.

Van Devender, T.R., 1987. Holocene vegetation and climate in the Puerto Blanco Mountains, southwestern Arizona. Quat. Res. 27, 51-72.

Vierling, L.A., 1998. Palynological evidence for late- and postglacial environmental change in central Colorado. Quat. Res. 49, 222-232.

Wagner, J.D.M., Cole, J.E., Beck, J.W., Patchett, P.J., Henderson, G.M., Barnett, H.R., 2010 Moisture variability in the southwestern United States linked to abrupt glacial climate change. Nat. Geosci. 3, 110-113.

Waters, M.R., 1989. Late Quaternary lacustrine history and paleoclimatic significance of pluvial Lake Cochise, southeastern Arizona. Quat. Res. 32, 1-11.

Webb, R.H., Betancourt, J.L., 1992. Climatic variability and flood frequency of the Santa Cruz, River, Pima County, Arizona. U.S. Geological Survey Water-Supply Paper, 2379. 40.

Weiss, J.L., Castro, C.L., Overpeck, J.T., 2009. Distinguishing pronounced droughts in the southwestern United States: seasonality and effects of warmer temperatures. J. Clim. 22, 5918-5932.

Wurster, F.C., Cooper, D.J., Sanford, W.E., 2003. Stream/aquifer interactions at Great Sand Dunes National Monument, Colorado: influences on interdunal wetland disappearance. J. Hydrol. 271, 77-100.

Yuan, F., Miyamoto, S., 2008. Characteristics of oxygen-18 and deuterium composition in waters of the Pecos River in American Southwest. Chem. Geol. 225, 220-230.

Yuan, F., Linsley, B.K., Lund, S.P., McGeehin, J.P., 2004. A 1200 year record of hydrologic variability in the Sierra Nevada from sediments in Walker Lake, Nevada. Geochem. Geophys. Geosyst. 5, 1-13.

Yuan, F., Linsley, B.K., Howe, S.S., 2006a. Evaluating sedimentary geochemical lake-leve tracers in Walker Lake, Nevada, over the last 200 years. J. Paleolimnol. 36, 37-54.

Yuan, F., Linsley, B.K., Howe, S.S., Lund, S.P., McGeehin, J.P., 2006b. Late Holocene lakelevel fluctuations in Walker Lake, Nevada, USA. Palaeogeogr. Palaeoclimatol. Palaeoecol. 240, 497-507. 